Библиография произведений Н.В. Гоголя и литературы о нем на русском языке (1981-1985)

V.A. Voropaev (Moscow, Russia)

\title{
The Bibliography of N.V. Gogol's Works and Literature about Him in Russian (1981-1985)
}

1981

\section{ПРОИЗВЕДЕНИЯ}

Вечера на хуторе близ Диканьки / Рис. И. Байрачного. Минск: Юнацтва, 1981. 191 с.: ил.

Избранное: В 2 т. / Редкол.: Ш. Муртазаев и др.; худ. А. Кулинич. Алма-Ата: Жазушы, 1981.

T. 1.

Т. 2.423 с.: ил.

Мертвые души: [поэма] / Послесл. и примеч. Ю.В. Манна. М., 1981. 398 с.

Загл. послесл.: В поисках живой души. С. 374-388.

Примеч. С. 389-397.

Мертвые души: поэма / Предисл. П.Г. Антокольского. М.: Художественная литература, 1981. 415 с.: ил.

Загл. предисл.: Мертвые души. С. 5-35.

Мертвые души: поэма / Ил. В. Горяева. М.: Художественная литература, 1981. 575 с.: ил. Приложение:

Повесть о капитане Копейкине. Редакция, разрешенная цензурой. С. 569-574.

Невский проспект: повесть / Рис. Д.Н. Кардовского. Л.: Изокомбинат «Художник РСФСР», 1981. 106 с.: ил.

[Факсимильное воспроизведение изд. 1905 г.]

[Откл.: Викторова E. Сокровища - для всех // Ленинградская правда. Л., 1981. 18 сентября.]

[Впервые: Невский проспект: Повесть Н.В. Гоголя / рис. Д.Н. Кардовского. СПб.: Кружок любителей русских изящных изданий, печатано в типографии Т-ва Р. Голике и А. Вильборг, 1905. [4]. 74 с.: ил.]

[150 нумерованных экземпляров.]

Несколько слов о Пушкине // Пушкин А.С. Собр. соч.: В 10 т. Т. 10. М.: Изд-во Правда, 1981. - (Библиотека «Огонек»). 
Петербургские повести / Вступ. статья С.Г. Бочарова. М.: Правда, 1981. 206 с.: ил. Загл. вступ. статьи: Петербургские повести Гоголя. С. 5-18.

Петербургские повести / Послесл. С.Г. Бочарова. Барнаул: Алтайское книжное изд-во, 1981. 175 с. - (Школьная библиотека).

Загл. послесл.: Петербургские повести Гоголя. С. 164-174.

Тарас Бульба: повесть / Вступ. статья Л.М. Полуяновой. Одесса: Маяк, 1981. 119 с. Загл. вступ. статьи: Он воспел любовь к Родине. С. 5-7.

Шинель: повесть / Послесл. Ю.В. Манна; рис. Ю. Игнатьева. М.: Детская литература, 1981. 47 с. - (Школьная библиотека).

Загл. послесл.: «Одно из величайших созданий Гоголя». С. 39-46.

\section{ЛИТ ЕРАТ У РА}

Аксаков К.С., Аксаков И.С. Литературная критика / Сост., вступ. статья и коммент. А.С. Курилова. М.: Современник, 1981. 383 с. - (Библиотека «Любителям российской словесности»).

Загл. вступ. статьи: Константин и Иван Аксаковы. С. 5-29.

Из содерж.:

Аксаков К.С. Несколько слов о поэме Гоголя «Похождения Чичикова, или Мертвые души. C. $141-150$.

[Впервые: отдельной брошюрой. М., 1842.]

Аксаков К.С. Объяснение <по поводу рецензии В.Г. Белинского на «Несколько слов о поэме Гоголя...»>. С. 151-158.

[Впервые: Москвитянин. 1842. № 9. Критика. С. 220-229.]

Коммент. С. 359.

Аксаков И.С. Несколько слов о Гоголе. С. 250-252.

[Впервые: Московский сборник. Т. 1. М., 1852. С. VII-XII.]

Коммент. С. 365.

[Указ. имен.]

Алексеев А., Наумов А. «Неправосудие, величайшее в свете несчастие...» (Право в творчестве Н.В. Гоголя) // Социалистическая законность. М., 1981. № 10. С. 57-59.

Альбом гоголевских типов // Приокская правда. Рязань, 1981. 15 августа.

[О выставке, посвященной 165 -летию художника П.М. Боклевского, на которой представлено прижизненное издание «Альбома гоголевских типов».]

Альми И.Л. Пушкинская традиция в комедии Гоголя «Ревизор» // Проблемы современного пушкиноведения. Л., 1981. С. 13-24.

Анненкова Е.И. Осмысление жизненных фактов в художественной концепции «Мертвых душ» Н.В. Гоголя // Пути анализа литературного произведения: Пособие для учителя / Под ред. Б.Ф. Егорова. М.: Просвещение, 1981. С. 20-30.

Анненский И. Заметки о Гоголе, Достоевском, Толстом / Публ. Н.Т. Ашимбаевой // Известия АН СССР. Сер. лит. и яз. М., 1981. Т. 40. № 4. С. 378-386.

Бердников Г. Гоголь и Чехов: К вопросу об исторических судьбах творческого наследия Н.В. Гоголя // Вопросы литературы. М., 1981. № 8. С. 124-162.

Блок А.А. Собр. соч.: В 6 т. Т. 4: Очерки. Статьи. Речи. 1905-1921 М.: Художественная литература, $1982.462 \mathrm{c}$.

Дитя Гоголя.

Вертлиб Е. От Гоголя до Гегеля, или «Мертвые души» в «Селе Степанчикове» Достоевского // Canad. Amer. Slavic Studies. Montreal, 1981. Vol. 15. № 4. P. 467-491. 
[Впервые: Современник. Торонто (Канада), 1979. № 42. С. 12-18; № 43/44. С. 77-85. Перепечатано: Дон. Ростов на Дону, 1997. № 1. С. 215-238; Вертлиб Е. Разнообрывки рифмованных мыслей. Note. СПб.: Терция, 1994. С. 91-138. Примеч. С. 176-185.]

Вишневская И. Нравственные искания Гоголя // Театральная правда. Тбилиси, 1981. C. 81-101.

Bоропаев B. «Замкни речь пословицей». Народнопоэтическая стихия в «Мертвых душах» Н.В. Гоголя // Литературная учеба. М., 1981. № 4. С. 172-179.

Воропаев B.A. «Мертвые души» и традиции народной культуры (Н.В. Гоголь и И.М. Снегирев) // Русская литература. Л., 1981. № 2. С. 92-107.

Гамсахурдиа К. Собр. соч.: В 8 т. Т. 7-8: Новеллы, очерки, статьи. Тбилиси: Мерани, 1981. Гоголь / Пер. П. Шариа. С. 495-514.

Гончар О. Гоголевскими шляхами // Литературная газета. М., 1981. 2 декабря. № 49. С. 6. [Гоголевская Полтавщина.]

Гончар О. Гоголевскими шляхами / Авторизов. пер. с укр. К. Григорьева // Радуга. Киев, 1981. № 12. С. 31-39.

Грибушин И.И. О поэтике социальной утопии (Гоголь и Некрасов) // Русская литература 1870-1890 гг. Свердловск, 1981. Сб. 14. С. 138-151.

Гураль С.К. Творчество Н.В. Гоголя в свете основных направлений современной американской критики // Современная идеологическая борьба и проблемы изучения и преподавания литературы, журналистики США / Тезисы докладов Всесоюзной конференции по проблемам американистики (22-24 сентября 1981, Москва). М.: Изд-во МГУ, 1981. С. 55-56.

Гус М.С. Живая Россия и «Мертвые души». М.: Советский писатель, 1981. 336 с.

Добин Е.С. Сюжет и действительность. Искусство детали. Л.: Советский писатель. Ленинградское отделение, 1981. 432 с.

[Гоголь: С. 311-363].

Друговская А.Ю., Капинос С.В. Из истории преследования царской цензурой «Письма к Гоголю» В.Г. Белинского // Научные труды / Курский пед. ин-т. Курск, 1981. Т. 216. C. $149-159$.

Зарубежные исследования по литературоведению: реферативный сб. Вып. 1 / Академия наук СССР. Институт научной информации по общественным наукам; материалы подгот. А.Н. Николюкиным и И.П. Ильиным; отв. ред. Е.Ф. Трушенко. М., 1981. 192 с. - (Сер. Направления и тенденции в современном зарубежном литературоведении и литературной критике).

Из содерж.:

Никитин В.А. Фэнджер Д. Творчество Николая Гоголя. С. 97-113.

[Fanger D. The creation of Nikoiai Gogol Cambridge (Mass.); London: Harvard University Press., 1979. XIII, 300 p.]

Золотусский И. Душа и дело жизни: Очерки о Гоголе. М.: Правда, 1981. 48 с. - (Библиотека «Огонек»).

Золотусский И. На земле Гоголя // Огонек. М., 1981. № 3. С. 14-15.

История русской литературы: В 4 т. Т. 2. От сентиментализму к романтизму и реализму / Академия Наук СССР. Институт Русской Литературы (Пушкинский Дом); гл. ред. Н.И. Пруцков; ред. тома Е.Н. Купреянова. Л.: Наука. Ленинградское отделение, 1981.880 с. Купреянова Е.Н. Н.В. Гоголь. С. 530-579. 
Иваньо И. Очерк развития эстетической мысли Украины. М.: Искусство, 1981. 423 с. [Указ. имен.]

Классическое наследие и современность:[сб. статей] / АН СССР, Институт русской литературы (Пушкинский Дом); редкол.: Д.С. Лихачев (отв. ред.) и др. Л.: Наука: Ленинградское отделение, 1981. 416 с.

Из содерж.:

Жаравина Л.В. К проблеме национального характера в поэме Гоголя «Мертвые души». С. 159-166. Кузьмин А.И. Гоголевские традиции в романах И. Ильфа и Е. Петрова «Двенадцать стульев» и «Золотой теленок». С. 285-294.

Каганская М. Апология жанра // 22 (Двадцать два): [альманах.] Тель-Авив, 1981. № 2. Июль - Август. С. 192-208.

[«Апология сумасшедшего» П.Я. Чаадаева как реакция на «Записки сумасшедшего» Гоголя.]

Коханова Л. Возвращение писателя // Смена. М., 1981. № 7. Апрель. С. 20.

[Квартира Гоголя в Москве.]

Кочемасов В.И. На благо общества // Литературная газета. М., 1981. 7 января. № 2. С. 10.

Кривонос В.Ш. Проблема читателя в творчестве Гоголя / Науч. ред. В.П. Скобелев. Воронеж: Изд-во Воронежского ун-та, 1981. 168 с.

Кубарев Е.М. Сопоставительно-текстологический анализ ключевой группы слов (как средство когезии) в авторских вариантах комедии Н.В. Гоголя «Ревизор» // Научные труды Куйбышевского гос. пед. ин-та. Т. 252: Художественная речь. Куйбышев, 1981. С. 12-138.

Ланский Л. Неизвестное об известном // В мире книг. М., 1981. № 3. С. 78-80.

[C. 80: Надпись Гоголя на форзаце прекрасно переплетенного экземпляра первого издания «Ревизора» (СПб., 1836): «Федору Лаврентьевичу Халчинскому от Автора». Экземпляр хранится в отделе редкой книги Государственной исторической биболиотеки (Москва). Надпись не датирована. Можно предположить, что сделана она весной 1836 г, вскоре после выхода книги в свет.]

Литвин Н.О., Брайко Г.С. Великосорочинский литературно-мемориальный музей Н.В. Гоголя: Путеводитель. 4-е изд. Харьков: Прапор, 1981. 62 с.: ил.

Лихачева И.В. Опера «Мертвые души» Р. Щедрина: Путеводитель. М.: Советский композитор, 1981. 81 с: ил., нот. ил.

Любас Л.А. «Женитьба» Н.В. Гоголя и «Бедная невеста» А.Н. Островского: Сопоставительная характеристика драматургии конфликта и драматургии диалога // Проблемы истории критики и поэтики реализма. Куйбышев, 1981. С. 87-98.

Люблю отчизну я... / Сост. И.В. Воробьева. М.: Детская литература, 1981. 494 с.

Манн Ю. Парадокс Гоголя-драматурга // Вопросы литературы. М., 1981. № 12. С. 132-147.

Молдавский Д.М. Товарищ Смех. Л.: Лениздат, 1981. 344 с.

Из содерж.:

О фольклоризме Гоголя. Предположение об имени «Вий». С. 143-153.

Николюкин А.Н. Литературные связи России и США. Становление литературных контактов / АН СССР, ИНИОН, Институт русской литературы (Пушкинский Дом). М.: Наука, 1981. 406 с.: ил.

[Гоголь и Ирвинг. С. 242-244.]

Осокин В. Заветная полка // Книжное обозрение. М., 1981. 18 сентября. 
Попов В.П. Отношение Гоголя к брошюре К. Аксакова о «Мертвых душах» // Эстетические взгляды писателя и художественное творчество: межвузовский сб. / Кубанский гос. ун-т; редкол.: В.А. Михельсон (отв. ред.) и др. Краснодар: Кубанский ун-т, 1981. С. 47-54.

Поспелов Г.Н. История русской литературы XIX века. 40-60-е годы. М.: Высшая школа, $1981.480 \mathrm{c}$.

Проблема традиций и новаторства в русской литературе XIX - начала XX вв.: межвузовский сб-к научных трудов / Министерство просвещения РСФСР, Горьковский гос. пед. ин-т им. М. Горького; редкол.: М.Я. Ермакова (отв. ред.), В.Г. Ермушкин, В.В. Харчев, А.Н. Орфанова, 3.Е. Либинзон. Горький, 1981. 151 с.

Из содерж.:

Короленок А.И. «Тарас Бульба» Гоголя и народная смеховая культура. С. 103-110.

Гольденберг А.Х. «Житие» Павла Чичикова и агиографическая традиция. С. 111-118.

Райку Л. Гоголь, или фантастика банального // Литература и жизнь народа: Литературно-художественная критика в СРР [Социалистическая Республика Румыния]: Сб. статей / Пер. с рум.; общ. ред. А.А. Языковой; сост. и предисл. М.В. Фридмана. М.: Прогресс, М., 1981. С. 394-404.

Раков Ю. Два портрета: Гоголь и Иванов // Литературная Россия. М., 1981. 18 декабря. № 51. C. 22.

Русская критика от Карамзина до Белинского / Сост., вступ. статья и коммент. А.А. Чернышева. М.: Детская литература, 1981. 400 с.

Из содерж.:

Пушикин А.С. Вечера на хуторе близ Дикеньки. Повести, изданные Пасичником Рудым Паньком. 2-е изд. Две части.

Гоголь Н.В. Несколько слов о Пушкине.

Гоголь Н.В.Театральный разъезд после представления новой комедии.

Гоголь Н.B. В чес же наконец существо русской поэзии и в чем ее особенность.

Шевырев С.П. Похождения Чичикова, или Мертвые души, поэма Н. Гоголя. Статья первая.

Шевырев С.П. Похождения Чичикова, или Мертвые души, поэма Н. Гоголя Статья вторая.

Аксаков К.С. Несколько слов о поэме Гоголя «Похождения Чичикова, или Мертвые души»

Гериен А.И. <Из дневника 1842 года.>

Белинский В.Г. О русской повести и повестях г. Гоголя («Арабески» и «Миргород»).

Белинский В.Г. Несколько слов о поэме Гоголя «Похождения Чичикова, или Мертвые души».

Белинский В.Г. Письмо к Н.В. Гоголю.

Русская литература XIX века. Первая половина: Хрестоматия литературно-критических, мемуарных и эпистолярных материалов / Сост. И.Е. Каплан, П.Г. Пустовойта. М.: Просвещение, 1981. 240 с.

Из содерж.:

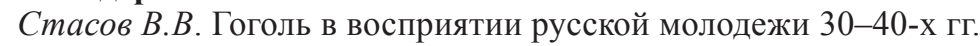

Русская литература в оценке современной зарубежной критики: [сб. статей. Вып. 3] / Под ред. проф. В.И. Кулешова. М.: Изд-во Московского ун-та, 1981. 288 с.

Из содерж.:

III. О спорном и бесспорном:

Пучкова Г.А. Неравноценные этюды о классиках (О сборнике «Русская литература ХІХ в.: Очерки о десяти русских писателях» под редакцией Дж. Феннелла). С. 130-179.

[Nineteenth-Century Russian Literature: Studies of Ten Russian Writers / Ed. by John Fennell. London: Faber and Faber, 1973.]

[Об очерке А. де Джонга «Гоголь»: С. 161-179.]

IV. Сообщения:

Гураль С.К. Ф. Дриссен о Гоголе-повествователе. С. 280-283. 
[Driessen F.C. Gogol' as Novellist. Bijdrage tot de kennis van zijn compositietechniek. Baarn Hollandia, 1955; Driessen F.C. Gogol as a Short-Story Writer. A Stydy of His Technique of Composition / Transl. from Dutch by Ian F. Finlay. Paris; The Hague; London: Mouton \& Co., 1965.]

Кулешов В.И. Упрощение сложного (О книге Д. Фэнгера «Творчество Гоголя»). С. 284-287.

[Fanger Donald. The Creation of Nicolai Gogol. The Belknap Press of Harvard University Press, 1979. 300 p.]

Сахарова E.M., Семибратова И.В. Энциклопедия русской жизни: Роман и повесть в России второй половины XVIII - начала XX века. Рекомендательный библиографический указатель / Под ред. проф. В.И. Кулешова. М.: Книга, 1981 / Гос. библиотека СССР им. В.И. Ленина. 384 с.

[Н.В. Гоголь. С. 77-91].

Сашина А. Самозваная родня литературных героев // В мире книг. М., 1981. № 6. С. 80. [Откл на кн.: Добчинский и Бобчинский. Как ловко надувают в Петербурге помещиков. СПб., 1865; Курдиновский А.И. Майская ночь или случай с писарем у пруда. Венок на памятник Н.В. Гоголю (Харьков, 1902) и др.]

Слюсарь А.А. Герои и ситуации в «Тарасе Бульбе» Н.В. Гоголя и «Хаджи-Мурате» Л.Н. Толстого // Вопросы литературы народов СССР. Киев; Одесса, 1981. Вып. 7. С. 64-74.

Смелянский А.М. Н.В. Гоголь // Смелянский А.М. Наши собеседники. М., 1981. С. 43-90.

Смирнова Е.А. Гоголь Николай Васильевич // Лермонтовская энциклопедия. М.: Изд-во Советская знциклопедия, 1981. С. 114-115.

Струве П.Б. Два русских ясновидца: Гоголь и Иванов // Струве П.Б. Дух и слово: Статьи о русской и западноевропейской литературе. Paris: YMCA-Press, 1981. С. 177-183.

Турчин В.C. Эпоха романтизма в России: К истории русского искусства первой трети 19 столетия: Очерки. М.: Искусство, 1981. 552 с.

[О Гоголе: С. 72-74.]

Хандрос Б.Н. Всматриваясь в лица: Художественно-документальные повествования Киев: Молодь, 1981. 191 с.

На Михайловой горе. С. 135-151.

[К истории отношений Гоголя и М.А. Максимовича].

Храпченко М.Б. Собр. соч.: В 4 т. Т. 3: Творческая индивидуальность писателя и развитие литературы. М.: Художественная литература, 1981. 431 с.

[Указ. имен.]

Червинский Н., Паншинская Н. Загадка диплома Н.В. Гоголя // Нева. Л., 1981. № 4. C. $220-221$.

[Приводится текст диплома Гоголя - почетного члена Московского университета.]

Шаблий М.И. Н.В. Гоголь и М.Ю. Лермонтов: (К истории вопроса об идейно-эстетической общности) // Вопросы русской литературы. Львов, 1981. Вып. 21. С. 43-51.

Шагинян Р.П. Белинский - основоположник русской классической критики: [Учебное пособие] / Самаркандский гос. ун-т им. А. Навои. Самарканд: Самаркандский гос. ун-т, $1981.90 \mathrm{c}$.

Шкловский В. Энергия заблуждения. Книга о сюжете. М.: Советский писатель, 1981. $352 \mathrm{c}$.

Из содерж: :

Гоголь. Почему не дописаны «Мертвые души». С. 309-325.

[«Мертвые души» «не дописаны потому, что их нельзя было воскресить».] 


\section{ПРОИЗВЕ ДЕНИЯ}

Вечера на хуторе близ Диканьки. Миргород / Послесл. П. Николаева. М.: Художественная литература, 1982. 432 с.: ил. - (Классики и современники. Русская классическая литература).

Послесл. С. $420-430$.

Избранные произведения. М.: Художественная литература, 1982. 583 с.

Мертвые души: поэма. М.: Московский рабочий, 1982. 384 с.

Мертвые души: поэма / Предисл. С.И. Машинского. М.: Детская литература, 1982. 384 с.: ил. - (Школьная библиотека).

Предисл. С. 3-22.

Мертвые души: поэма / Послесл. М. Рукавицина. М.: Московский рабочий, 1982. 382 с. Послесл. С. 365-381.

Высказывания и отзывы о поэме

Приложение

Повесть о капитане Копейкине. Редакция, разрешенная цензурой.

Мертвые души: поэма / Предисл. С.И. Машинского; примеч. М.Г. Качурина; ил. А. Агина, П. Боклевского, А. Лаптева. М.: Просвещение, 1982. 256 с.: ил. - (Школьная библиотека). Загл. вступ. статьи: О великой поэме Гоголя. С. 5-22.

Примеч. С. 236-253.

Приложения:

Повесть о капитане Копейкине. Редакция, разрешенная цензурой. С. 224-228.

Н.В. Гоголь о «Мертвых душах». Из писем и произведений. Сост. М.Г. Качурин. С. 229-235.

Ревизор / Послесл. В. Цаавы. Тбилиси, 1982. 160 с.

Загл. послесл.: Гоголевская ревизия (О «Ревизоре»). С. 135-159.

Ревизор. Мертвые души Шинель. Салтыков-Щедрин М.Е. Господа Головлевы. Сказки. М.: Детская литература, 1982.718 с. - (Библиотека мировой литературы для детей).

Тюнькин К.И. Вершины русской сатиры. С. 3-42.

Мертвые души: поэма. М.: Московский рабочий, 1982. 384 с.

Переписка Пушкина. Т. 2. М.: Художественная литература, 1982. - (Сер. Переписка русских писателей).

Шинель: повести. М.: Советская Россия, 1982. 63 с. - (Школьная библиотека).

Содерж:

Шинель. С. 5-35.

Hoc. C. 36-61.

Шинель / Послесл. Ю. Манна. Изд. 3-е. М. Детская литература, 1982. 47 с. - (Школьная библиотека. Для средней школы).

Загл. послесл.: Одно из глубочайших созданий Гоголя. С. 39-46.

\section{ЛИТЕРАТ УРА}

Авдонин А.М. Неосуществленное намерение Н.В. Гоголя, или История одной легенды // Русская литература. Л., 1982. № 2. С. 195-196.

[О намерении Гоголя посетить Симбирск.]

Аксаков К.С., Аксаков И.С. Литературная критика / Сост., вступ. статья и коммент. А.С. Курилова. М.: Современник, 1982. 383 с. - (Библиотека «Любителям российской словесности». Из литературного наследия). 
Загл. вступ. статьи: Константин и Иван Аксаковы. С. 5-29.

Из содерж.:

Аксаков К.С. Несколько слов о поэме Гоголя «Похождения Чичикова, или Мертвые души. C. $141-150$.

[Впервые: отдельной брошюрой. М., 1842.]

Аксаков К.С. Объяснение <по поводу рецензии В.Г. Белинского на «Несколько слов о поэме Гоголя...»>. С. 151-158.

[Впервые: Москвитянин. 1842. № 9. Критика. С. 220-229.]

Коммент. С. 359.

Аксаков И.С. Несколько слов о Гоголе. С. 250-252.

[Впервые: Московский сборник. Т. 1. М., 1852. С. VII-XII.]

Коммент. С. 365.

[Указ. имен.]

Алексеев М.П. Русско-английские литературные связи (XVIII век - первая половина XIX века) // Литературное наследство. Т. 91. М.: Изд-во Наука, 1982. 863 с.

[Ганц Кюхельгартен: С. 697-700.]

[Указ. имен.]

Альтман M.C. О собственных именах в произведениях Гоголя // Finitis Duodecim Lustris: сб. статей к 60-летию проф. Ю.М. Лотмана. Таллин. 1982. С. 106-109.

Аннинский Л. «Юбиляр во фраке...» (Не лишенный загадочности эпизод из жизни Афанасия Фета) // Московский комсомолец. М., 1982. 13 августа.

[Гоголь и А. Фет.]

Афанасьев В.В., Боголепов П.К. Тропа к Лермонтову: Документально-художественная книга-справочник жизни и творчества М.Ю. Лермонтова / Под общ. ред. В.И. Коровина. М.: Детская литература, 1982. 286 с.: 96 л. ил.

Из содерж.:

Афанасьев В.В. Окружение Лермонтова (избранные лица). Гоголь Николай Васильевич (18091852). C. 98-99.

Бекедин Б.В. В.Г. Белинский и проблема эпопеи // Русская литература. Л., 1982. № 3. C. $38-55$.

[Полемика В.Г. Белинского с К.С. Аксаковым о «Мертвых душах» Гоголя.]

Белинский В.Г Собр. соч.: В 9 т. / Редкол.: Н.К. Гей и др. М., 1976-1982.

Бельй А. Мастерство Гоголя: Исследование. Ann Arbor: Ardis Publishers, 1982. 319 с.

Виноградов B.B. Очерки по истории русского литературного языка XVII-XIX веков. 3-е изд. М.: Высшая школа, 1982. 528 с.

Владимиров E.B. Н.В. Гоголь в чувашской литературе // Владимиров Е.В. Обретение традиций. Чебоксары, 1982. С. 100-108.

Войтоловская Э.Л. С.Т. Аксаков в кругу писателей-классиков: Документальные очерки. Л.: Детская литература, 1982. 220 с.: ил. - (Школьная библиотека).

Аксаков и Гоголь. С. 91-151.

Воронский А.К. Избранные статьи о литературе / Вступ. статья А.Г. Дементьева. М.: Художественная литература, 1982. 527 с.

Из книги «Гоголь». С. 445-522.

[Рец.: Николаев П. Вера в художественную истину // Новый мир. М., 1983. № 8. С. 240-244.]

Воропаев В. Рукою Гоголя // Огонек. М., 1982. Октябрь. № 43. С. 15.

[Записка Гоголя графине Л.К. Виельгорской «Разные дела по части Гоголя» (1844).]

Bоропаев B.A. Заметки о фольклорном источнике гоголевской «Повести о капитане Копейкине» // Научные доклады высшей школы. Филологические науки. М., 1982. № 6. С. 35-41. 
Boponaев B.A. О роли пословиц в создании характеров «Мертвых душ» Н.В. Гоголя // Проблемы литературного развития (на материале русских и зарубежных литературно-художественных традиций): сб. статей. М.: Изд-во Московского ун-та, 1982. С. 48-59.

Воскерчян А.К. Всемирное значение творчества Гоголя // Воскерчян А.К. Вопросы русской и армянской литературы. Ереван, 1982. С. 110-118.

Вяземский П.А. Сочинения: В 2 т. Т. 1: Стихотворения / Сост., подгот. текста, вступ. статья и коммент. М.И. Гиллельсона. М.: Художественная литература, 1982. 462 с.

Загл. вступ. статьи: Петр Андреевич Вяземский. С. 5-36.

Из содерж.:

Поминки $<$ Гоголь $>$ («Ты загадкой своенравной...»). С. 282-283.

Вяземский П.А. Сочинения: В 2 т. Т. 2: Литературно-критические статьи / Сост., подгот. текста и коммент. М.И. Гиллельсона. М.: Художественная литература, 1982. 383 с.

Из содерж: :

«Ревизор». Комедия. Соч. Н. Гоголя. С-Петербург, 1836 г. С. 146-162.

[Впервые: Современник. 1836. Т. 2. С. 285-309.]

Коммент. С. 341-343.

Языков и Гоголь. С. 162-188.

[Впервые: Санкт-Петербургские ведомости. 1847. 24-25 апреля. № 90-91.]

Коммент. С. 343-346.

Приложение:

Из «Автобиографического введения». С. 239-280.

[О Гоголе: С. 274-276.]

[Впервые: Вяземский П.А. Полное собр. соч. СПб., 1878. Т. 1. С. I-LX; T. 2. C. VII-XVIII.]

[Печ. с уточнением по рукописи.]

Коммент. С. 355-363.

[Указ. имен.]

Гольденберг А.X. Житийная традиция в «Мертвых душах» // Литературная учеба. М., 1982. № 3. С. 155-162.

Громов М.П. О гоголевской традиции у Чехова // Чехов и литература народов Советского Союза. Ереван: Изд-во Ереванского гос. ун-та, 1982. С. 55-76.

Гураль С.К. Творчество Н.В. Гоголя в современной американской критике (по материалам книг Т. Линдстром «Краткая история русской литературы» и «Николай Гоголь») // Проблемы метода и жанра. Томск: Изд-во Томского ун-та, 1982. С. 154-163.

Дилакторская О. О «Шинели» Н.В. Гоголя: Построение сюжета // Литературная учеба. М., 1982. № 3. С. 149-154.

Докусов А.М., Качурин М.Г. Поэма Н.В. Гоголя «Мертвые души» в школьном изучении: Пособие для учителя. М.: Просвещение, 1982. 194 с.

Дубинин М. Гоголь и Оптинские старцы // Новый журнал. Нью-Йорк, 1982. № 147. С. 5-17.

Егоров Б.Ф. Борьба эстетических идей в России середины XIX века. Л.: Искусство. Ленинградское отделение, 1982. 269 с.

[Указ. имен.]

Егоров Б.Ф. Литературно-критическая деятельность В.Г. Белинского: Пособие для учителя. М.: Просвещение, 1982. 175 с.

Из содерж.:

Разд. I: У истоков литературно-критической деятельности

«О русской повести и повестях г. Гоголя». С. 29-32.

Разд. III: Время критических шедевров 
Статьи о «Мертвых душах». С. 92-101.

Разд. IV: Борьба за «натуральную школу»

«Лучшее произведение бесцензурной демократической печати». С. 153-158.

[Письмо В.Г. Белинского к Гоголю от 15 июля (н. ст.) 1847 г. из Зальцбрунна.]

Жаравина Л.В. Шекспиризм Гоголя: к постановке проблемы // Литературно-критические опыты и наблюдения. Вопросы русского языка и литературы. Кишинев: Штиинца, 1982. С. 3-12.

Жаравина Л.В., Компанееи В.В. Идейно-эстетические искания позднего Гоголя и проблема художественного метода // Эстетические позиции и художественное мастерство писателя. Вопросы русского языка и литературы. Кишинев: Штиинца, 1982. С. 16-28.

Живоглядов А.А. Особые случаи переводов смысловых имен собственных (На материале перевода поэмы Н.В. Гоголя «Мертвые души» на английский язык) // Теория и практика перевода. Киев, 1982. Вып. 7. С. 60-72.

Жирмунский В.М. Избранные труды. Гете в русской литературе. Л.:Наука, 1982. 560 с. [Поэма Гоголя «Ганц Кюхнльгартен»: С. 49, 68.]

Залыгин С.П. Читая Гоголя: Размышления и заметки // Залыгин С.П. Литературные заботы. 3-е изд. доп. М., 1982. С. 294-321.

Заславский И.Я. Пушкин и Украина. Киев: Вища школа, 1982. 151 с.

[О влиянии украинского фольклора на творчество Гоголя: С. 70-76.]

Зубков В.А. Жанр «Мертвых душ» Н.В. Гоголя в свете кольцевой композиции // Проблемы типологии литературного процесса. Пермь, 1982. С. 44-56.

История русской драматургии: В 2 т. Т. 1: XVII - первая половина XIX века / АН СССР. Институт русской литературы (Пушкинский Дом); отв. ред. Л.М. Лотман. Л.: Наука, 1982. 531 с.

Манн Ю.В. Драматургия Н.В. Гоголя. С. 426-473.

Канашкин В. Уроки народности: Статья 5 // Кубань. Краснодар, 1982. № 10. С. 84-91. [Русский национальный характер в творчестве русских писателей (в том числе Гоголя).]

Карташова И.В. Своеобразие романтической позиции Гоголя в «Миргороде» // Проблемы эстетики и творчества романтиков. Калинин, 1982. С. 90-122.

Ключевский В.О. Неопубликованные произведения. М.: Наука, 1983. 417 с.

Мысли о русских писателях

Н.В. Гоголь. С. 312-316.

[Впервые: Ключевский В.О. Неоконченная статья о Н.В. Гоголе (Из неопубликованных материалов) [1892] // Записки отдела рукописей Гос. библиотеки СССР им. Ленина. Вып. 24. М., 1961. C. 409-414.]

Короленок А.И. Шолохов и Гоголь: (К вопросу о традициях в «Тихом Доне») // Жанрово-композиционное своеобразие реалистического повествования. Вологда, 1982. С. 3-25.

Костова Н. [Рецензия] // Болгарская русистика. София, 1982. № 5. С. 90-95.

[Рец. на кн.: Троев Петко. Гогол. София: Нар. просвета, 1981. 138 с., 8 отд. л. ил. - (Библ. Творчески портрети).]

Кулешов В.И. Этюды о русских писателях (Исследования и характеристики). М.: Издво Московского ун-та, 1982. 264 с.

Из содерж.:

Гротескность сюжета «Ревизора». С. 73-76.

Ласский Ю. Выигрыши и проигрыши инженера Германа, майора Ковалева и художника Чарткова // Литературная учеба. М., 1982. № 1. С. 136-144. 
[Фантастическое у А.С. Пушкина и Гоголя.]

Листрова Ю.Т. Художественные функции иносистемных языковых явлений (вкраплений) в творчестве Н.В. Гоголя // Коммуникативная и поэтическая функция художественного текста. Воронеж, 1982. С. 149-156.

Лихачев Д.С. Память истории священна // Огонек. М., 1982. № 29. Июль. С. 19-20.

Макогоненко Г. Тема Петербурга у Пушкина и Гоголя: Проблемы преемственного развития // Нева. Л., 1982. № 8. С. 150-159.

Манн Ю. «Через душу живу» // Литературная учеба. М., 1982. № 3. С. 142-148.

[О работе Гоголя над «Мертвыми душами»].

Манн Ю.В. Поэтика Гоголя. 2-е изд., доп. М.: Художественная литература, 1982. 412, [1] с.

Маркович В.M. Тургенев и русский реалистический роман XIX в. Л.: Изд-во Ленинградского ун-та, 1982. $208 \mathrm{c}$.

Гоголь: С. 29-32.

Масальская Г.И. Гоголевские традиции комического в литературе натуральной школы (Сатира А.Н. Плещеева) // Вопросы русской литературы. Львов, 1982. Вып. 2(40). C. $49-55$.

Машковцев Н.Г. Из истории русской художественной культуры. Исследования, очерки, статьи / Сост. Т.Н. Горина, А.Н. Машковцева. М.: Советский художник, 1982. 328 с.: ил. Из содерж.:

Гоголь в кругу художников: С. 82-131.

[Указ. имен.]

Паперный В.M. Андрей Белый и Гоголь. Статьи I-III // Ученые записки Тартуского ун-та. Тарту, 1982. Вып. 604. С. 112-126; Тарту, 1983. Вып. 620. С. 85-98; Тарту, 1986. Вып. 683. С. 50-65. Труды по русской и славянской филологии. Литературоведение.

Паперный В.М. Андрей Белый и Гоголь: Статья первая // Единство и изменчивость историко-литературного процесса / Ученые записки / Тартуский гос. ун-т. Труды по русской и славянской филологии. Литературоведение. Тарту, 1982. Вып. 604. С. 112-126.

Пенкин М.С. Искусство и наука: Проблемы, парадоксы, поиски. М.: Современник, 1982. $302 \mathrm{c}$.

Парадокс Гоголя. С. 171-204.

Первушин Н.В. О Гоголе и Блоке // Русское Возрождение. Нью-Йорк; Москва; Париж, 1982. № 1(17). С. 137-152.

Переверзев В.Ф. Гоголь; Достоевский: Исследования / Сост. В.В. Переверзев. М.: Советский писатель, $1982.512 \mathrm{c.}$

Поляков А. В.Ф. Переверзев и проблемы поэтики. С. 5-38.

Творчество Гоголя: монография. С. 39-187.

[Рец: Раков В. Литературное обзрение. М., 1983. № 5. С. 80-81; Николаев П. Вера в художественную истину // Новый мир. М., 1983. № 8. С. 240-244; Гуральник У. Валерьян Переверзевисторик русской литературы // Вопросы литературы. М., 1983. № 12. С. 224-230; Шрамков $B$. Сохраняет силу аргумента // Подъем. Воронеж, 1984. № 7. С. 141-143.]

Поламишев А.М. Театр Н.В. Гоголя: Природа театральной прозы писателя. М.: Советская Россия, 1982. 118 с.: ил.

Порудоминский В. 26 апреля 1909 года. Повествование-хроника // Панорама искусств. М., 1982. № 5. С. 88-108. 
Поэтика. Труды русских и советских поэтических школ / Сост. Д. Кирай, А. Ковач. Будапешт: Изд-во: «Tankonyvkiado», 1982. 800 с.

Эйхенбаум Б.М. Как сделана «Шинель» Гоголя.

Русская эстетика и критика 40-50-х годов XIX века / Подгот. текста, сост., вступ. статья и примеч. В.К. Кантора и А.Л. Осповата. М.: Искусство, 1982. 544 с. - (История эстетики в памятниках и документах).

Загл. вступ. статьи: Русская эстетика середины XIX века: теория в контексте художественной культуры. С. 7-41.

\section{Из содерж.:}

Аксаков К.С. Несколько слов о поэме Гоголя «Похождения Чичикова, или Мертвые души». С. 42-53. Примеч. С. 503-504.

[Впервые: Несколько слов о поэме Гоголя «Похождения Чичикова, или Мертвые души». М., 1842.]

Шевырев С.П. Похождения Чичикова, или Мертвые души. Поэма Н. Гоголя. Статья вторая. C. $54-80$.

Примеч. С. 504-507.

[Впервые: Москвитянин, 1842. Ч. 4. № 8. Критика. С. 346-376.]

Майков В.Н. Нечто о русской литературев 1846 году. С. 81-105.

Примеч. С. 507-512.

[Впервые: Отечественные Записки. 1847. Т. 50. № 1. Отд. V. С. 1-17. Без подписи.]

Григорьев А.А. Гоголь и его последняя книга. С. 106-125.

Примеч. С. $510-512$.

[Впервые: Московский Городской Листок. 1847. 10 марта. № 56; 17 марта. № 62; 18 марта. № 63; 19 марта. № 64. Подпись А. Г.]

Белинский В.Г. Письмо к Н.В. Гоголю. С. 192-201.

Примеч. С. 518-519.

[Впервые: Полярная звезда на 1855 год. Лондон, 1855. Кн. 1. С. 65-75.]

Аксаков И.С. Несколько слов о Гоголе. С. 284-286.

Примеч. С. 524-525.

[Впервые: Московский сборник. Т. 1. М., 1852. С. VII-XII. Без подписи.]

[Указ. имен.]

Сахаров В.И. Молодой Гоголь и романтическая традиция // Литературная учеба. М., 1982. № 5. С. 160-169.

Селезнев Ю.И. Мысль чувствующая и живая: Литературно-критические статьи. М.: Современник, $1982.336 \mathrm{c}$.

Из содерж.:

Созидающая память. С. 51-55.

Сергеев Н. Гоголь и Блок // Вестник РХД. Париж, 1982. № 1/2(136). С. 177-188.

Симачева И.Ю. Гоголь и А. Белый // Русская речь. М., 1982. № 2.

Слюсарь А.А. О сюжетных мотивах в «Повестях Белкина» А.С. Пушкина и «Вечерах на хуторе близ Диканьки» Н.В. Гоголя // Вопросы русской литературы. Львов, 1982. Вып. 2(40). С. 93-101.

Смирнова Е.А. О многосмысленности «Мертвых душ» // Контекст. 1982. Литературно-теоретические исследования: сб. статей. М.: Наука, 1983. С. 164-191.

Сохряков Ю.И. Восприятие творчества Н.В. Гоголя в США // Научные доклады высшей школы. Филологические науки. М., 1982. № 4. С. 24-32.

Станчева A. Корни идейно-художественного пафоса повестей Гоголя // Болгарская русистика. София, 1982. № 4. С. 56-73. 
Супрунюк Честь и долг. На Полтавщине создается заповедник-музей Н.В. Гоголя // Правда Украины. Киев, 1982. 8 декабря.

Сурков Е.А. Тип героя и жанровое своеобразие повести Н.В. Гоголя «Шинель» // Типологический анализ литературного произведения: сб. научных трудов / Кемеровский гос. ун-т. Кемерово, 1982. С. 67-74.

[Сопоставление повести Гоголя с Житием Феодосия Печерского.]

Тезисы докладов Первых Гоголевских чтений / Министерство просвещения УССР, Министерство культуры УССР, Полтавский гос. пед. ин-т им. В.Г. Короленко и др. Полтава, 1982. $116 \mathrm{c}$.

Из содерж.:

Петренко О.И. Творчество Гоголя - достояние братских литератур. С. 11-12.

Михальский Е.Н. Вопросы изучения стиля Гоголя. С. 13-14.

Мирный В.П., Пересыпкин А.А. Дидактические взгляды Н.В. Гоголя. С. 20-22.

Любченко В.Г. Гоголь в Чехословакии. С. 23-25.

Самойленко Г.В. Н.В. Гоголь в восприятии и оценке А. Фадеева. С. 38-39.

Виролайнен М.Н. Проблема замкнутой формы в эстетике Гоголя. С. 44-45.

Гетман И.М. Театральность образа в поэме Н.В. Гоголя «Мертвые души». С. 54-56.

Бобырь А.В. Гоголевские традиции в творчестве Е.Н. Чирикова. С. 65-66.

Заславский И.Я. Н.В. Гоголь и М.А. Максимович. С. 72-73.

Михед П.В. Н.В. Гоголь и украинская культура народного барокко. С. 85-87.

Ковальчук А. Хронотоп дороги в романах «Мертвые души» Н.В. Гоголя и «Твоя заря» О. Гончара. С. 91-92.

Сулыма Н.М. Н.В. Гоголь и украинская древняя литература. С. 93.

Яценко М.Т. Типология комического в творчестве И. Котляревского и Н. Гоголя. С. 94.

Турбин В.Н. К нам едет «Ревизор» // Современная драматургия. М., 1982. № 2. С. 262-270.

Федоров Н. Проективное определение литературы в «Мертвых душах» / Публ. и примеч. С. Семеновой // Литературная учеба. М., 1982. № 3. С. 163-168.

Финк Э.Л. Эволюция смысла гоголевской комедии «Ревизор» и движение времени // Поэтика реализма. Куйбышев, 1982. С. 111-133.

Фролова Т.С. Повести М.А. Булгакова «Дьяволиада», «Роковые яйца») и гоголевская литературная традиция // Художественное творчество и литературный процесс: сб. статей. Томск, 1982. Вып. 3. С. 28-40.

Хализев B. Писатель и народная бытовая эстетика: Гоголь, Лесков, их современники и продолжатели // Литературная учеба. М., 1982. № 3. С. 131-141.

Храпченко М.Б. Горизонты художественного образа. М.: Художественная литература, 1982. 332, [2] c.

Незавершенные замыслы и их истолкование. С. 244-251.

[2-й том «Мертвых душ» Гоголя.]

Шнейдер M.Е. Переработка как метод включения русской классики в китайскую литературу (На примере произведений Ф.М. Достоевского и Н.В. Гоголя) // Русская классика в странах Востока: сб. статей. М., 1982. С. 175-183. - (Институт востоковедения).

Шоки М. Роль индивидуальных фразеологизмов в «Мертвых душах» Н.В. Гоголя // Studia russica. 5. Будапешт, 1982. С. 93-97.

Шубин Вл. «Квартира моя... в доме Брунста» // Нева. Л., 1982. № 12. С. 192-194.

Юзовский Ю. Мейерхольд // О театре и драме: В 4 т. Т. 1. М.: Искусство, 1982. С. 332-338. 
Языков Н.М. Сочинения / Сост., вступ. статья примеч. А.А. Карпова. М.: Художественная литература, 1982. $448 \mathrm{c.}$

Загл. вступ. статьи: Судьба Николая Языкова. С. 3-20.

Примеч. С. 392-432.

Из содерж.:

Н.В. Гоголю («Благословляю твой возврат...»): [стихотворение]. С. 189-190.

Письма к Н.В. Гоголю. С. 380-385.

[Указ имен.]

Finitas Duodecim Lustris: сб. статей к 60-летию проф. Ю.М. Лотмана / Редкол.: С.Г. Исаков (отв. ред.) и др. Таллин: Ээсти раамат [Эстонская книга], 1982. 176 с.

Из содерж.:

Черныш Г.Г. Неизвестное письмо Гоголя. С. 109-116.

[Письмо Гоголя к В.А. Панову от 24 сентября 1841 г.]

Белоусов А.Ф. О гоголевском подтексте рассказа И.С. Тургенева «Бурмистр». С. 116-120.

\section{3}

\section{ПРОИЗ ВЕДЕНИЯ}

Н.В. Гоголь. Книга для чтения с комментарием. Русская литература для иностранного читателя / Сост., вступ. статья, коммент. Л.М. Крупчанова.

Вступ. статья. С. 5-12.

Коммент. С. 247-304.

Избранное / Послесл. П.А. Николаева. Свердловск: Средне-Уральское книжное изд-во, 1983. $527 \mathrm{c}$.

Загл. послесл.: Художественные открытия Гоголя. С. 508-522.

Избранные произведения: В 2 т. Киев: Дніпро, 1983. 406 с.

Т. 1: Вечера на хуторе близ Диканьки; Миргород: повести / Вступ. статья О. Гончара. 406 с.

Загл. вступ. статьи: Гоголь и Украина. С. 5-14.

Т. 2: Мертвые души; Ревизор: поэма, пьеса. 415 с.

Мертвые души: поэма / Предисл. П. Антокольского. М.: Художественная литература, 1983. 415 с.: ил.

Загл. предисл.: Мертвые души. С. 5-35.

Мертвые души: поэма. М.: Художественная литература, 1983. 416 с.: ил.

Мертвые души: поэма / Вступ. статья С.И. Машинского; худож. С.К. Артюшенко. Киев: Веселка, 1983. 420 с.: ил.

Загл. вступ. статьи: О великой поэме Гоголя. С. 5-24.

Петербургские повести. Ревизор: комедия / Послесл. Ю.В. Манна. Красноярск: Книжное изд-во, 1983. 272 с. - (Школьная библиотека)

Загл. послесл.: Сила «Ревизора». С. 260-269.

Повести / Вступ. статья, примеч., библиографические списки Л.В. Барбашовой, В.М. Гуминского; послесл. У.М. Спектора; ил. П.Б. Розенберга. М.: Книга, 1983. 480 с. [Миниатюрный формат.]

Загл. вступ. статьи: Гоголь и «Миргород». С. 5-58.

Примеч. С. 423-457.

Загл. послесл.: Н.В. Гоголь и миниатюрная книга. С. 458-474.

Библиографические списки. С. 475-478.

Содерж.: Старосветские помещики; Вий, Повесть о том, как поссорился Иван Иванович с Иваном Никифоровичем.

Повести: Книга для чтения с комментарием / Вступ. статья и коммент. Л.М. Крупчанова. М.: Русский язык, 1983. 305 с. - (Русская литература для иностранного читателя). 
Загл. вступ. статьи: Повести Н.В. Гоголя. 1809-1852. С. 5-12.

Повести. Драматические произведения. Л.: Художественная литература, 1983. 328 с. (Классики и современники. Русская классическая литература).

Пьесы / Примеч. Ю.В. Манна; ил. С.А. Алимова. М.: Правда, 1983. 272 с.: ил.

Примеч. С. 261-271.

Содерж.:

Ревизор. С. 3-92.

Женитьба. С. 93-150.

Драматические отрывки и отдельные сцены

Игроки. С. 153-190.

Утро делового человека. С. 191-198.

Тяжба. С. 199-205.

Лакейская. С. 206-212.

Отрывок. С. 213-225.

Театральный разъезд после представления новой комедии. С. 226-260.

Ревизор: комедия в пяти действиях / Вступ. статья, подбор материалов, историческая справка о постановках «Ревизора» и примеч. Вл. Филиппова. 10-е изд. М.: Детская литература, 1983. 176 с.: 8 л. фотоил.

Загл. вступ. статьи: «Ревизор» Н.В. Гоголя. С. 5-24.

Приложения:

Гоголь Н.В. Отрывок из письма, писанного автором вскоре после первого представления «Ревизора» к одному литератору. С. 111-116.

Гоголь Н.В. Предуведомление для тех, которые пожелали бы сыграть как следует «Ревизора». C. $117-124$.

Из писем Н.В. Гоголя. С. 125-128.

«Ревизор» на сцене: Историческая справка. С. 129-135.

Ильинский И. Моя работа над ролью Хлестакова и городничего. С. 136-149.

Примеч. С. 150-158.

Фотоиллюстрации к «Ревизору». С.159-175.

Собр. соч.: В 7 т. / Под общей ред. С.И. Машинского и М.Б. Храпченко. М.: Современник, 1983.

[Текст печ. по изд.: Гоголь Н.В. Собр. соч.: В 7 т. М.: Хужожественная литература, 1976-1979.] [Формат 70x 108.]

Т. 1. Вечера на хуторе близ Диканьки / Примеч. А.В. Чичерина, Н.Л. Степанова. 479 с.

Приложения:

Ганц Кюхельгартен. С. 317-363.

Две главы из малороссийской повести «Страшный кабан». С. 364-382.

Гетьман. С. 383-447.

Примеч. С. 448-478.

[Сопроводит. статья:] Чичерин А.В. Ранний Гоголь-романтик С. 448-465.

Примеч. Степпанов Н.Л. С. 465-478.

Т. 2. Миргород / Примеч. С.И. Машинского. 479 с.

Приложение:

Тарас Бульба (редакция «Миргорода» 1835 г.). С. 343-444.

Примеч. С. 445-478.

[Сопроводит. статья:] Миргород. С. 445-466.

Примеч. С. 466-478.

Т. 3. Повести / Примеч. Г.М. Фридлендера. 447 с.

Приложения:

Портрет (Редакция «Арабесок»). С. 334-394.

Ночи на вилле. С. 395-398.

Мелкие отрывки

Страшная рука. С. 399. 
$<$ Фонарь умирал.> С. 399-402.

<Дождь был продолжительный.> С. 402-404.

$<$ Рудокопов.> С. 404.

$<$ Семен Семенович Батюшек.> С. 404-406.

<Девицы Чабловы.> С. 406-407.

Примеч. С. 408-446.

[Сопроводит. статья:] Повести Гоголя. С. 408-427.

Примеч. С. 427-446.

Т. 4. Драматические произведения / Примеч. Ю.В. Манна. 639 с.

\section{Приложения:}

Приложения к комедии «Ревизор»

1. «Ревизор» (редакция первого издания, 1836 г.). С. 375-492.

2. Две сцены, выключенные при первом издании как замедлявшие течение пьесы. С. 493-498.

3. Сцена, не внесенная автором в печатные издания «Ревизора». С. 499-500.

4. Отрывок из письма, писанного автором вскоре после первого представления «Ревизора»к одному литератору. С. 501-508.

5. Предуведомление для тех, которые пожелали бы сыграть как следует «Ревизора». С. 509-520.

6. Развязка «Ревизора». С. 521-538.

7. Вторая редакция окончания «Развязки «Ревизора»». С. 539-547

Владимир 3-ей степени. С. 548-558.

Альфред. С. 559-587.

Наброски драмы из украинской истории. С. 588-592.

Примеч.: С. 593-637.

[Сопроводит. статья:] Драматургия Гоголя. С. 593-619.

Примеч.: С. 619-637.

Т. 5. Мертвые души: поэма / Примеч. С.И. Машинского. 830 с.

Приложения:

Повесть о капитане Копейкине (Редакция, разрешенная цензурой). С. 747-754.

$<$ Заметки> к 1-й части. С. 754-757.

Предисловие ко второму изданию первого тома «Мертвых душ». С. 757-762.

Примеч. С. 763-828.

[Сопроводит. статья:] «Мертвые души». С. 765-805.

Примеч. С. 806-828.

Т. 6. Статьи / Примеч. Ю.В. Манна. 830 с.

Приложение:

Петербургская сцена в 1835-36 г. С. 697-714.

Примеч. С. 715-827.

[Сопроводит. статья:] Гоголь- критик и публицист. С. 715-740.

Примеч. С. 740-827.

Т. 7. Письма / Вступ. статья и примеч. Г.М. Фридлендера. 639 с.

Загл. вступ. статьи: Письма Гоголя. С. 5-36.

Примеч. в тексте.

Приложение:

$<$ Письмо к> В.Г. Белинскому. Конец июля - начало августа 1847 г. С. 543-557.

[Шарыпкин Д.М.] Хронологическая канва жизни и творчества Н.В. Гоголя. С. 558-587.

[Шарыпкин Д.М.] Алфавитный указатель имен и названий к томам 6 и 7. С. 588-628. [Указатель имен аннотированный.]

Тарас Бульба: повесть / Послесл. С. Машинского. Ереван: Луйс, 1983. 176 с. - (Школьная библиотека).

Загл. послесл.: Гениальная повесть Гоголя. С. 155-175. 


\section{Л И Т Е РАТ У РА}

Аврамеи И.А. «Портрет» Н.В. Гоголя и «Хозяйка» Ф.М. Достоевского (К проблеме типологического родства) // Ученые записки / Тартусский гос. ун-т. Тарту, 1983. Вып. 620. С. 42-49.

Алексеев М.П. Сравнительное литературоведение. Л.: Наука, 1983. 487 с.

Из содерж.:

Гоголь и Т. Мур. С. 341-350.

Андроникашвили Б. Потомки Вахтанга VI // Литературная Грузия. Тбилиси, 1983. № 3. C. $191-213$.

[О взаимоотношениях Гоголя с графами А.П. и А.Г. Толстыми.]

Анненков П.В. Литературные воспоминания / Вступ. статья В.И. Кулешова; коммент. А.М. Долотовой, Г.Г. Елизаветиной, Ю.В. Манна, И.Б. Павловой. М.: Художественная литература, 1983. 694 с. - (Серия литературных мемуаров).

Загл. вступ. статьи: П.В. Анненков - мемуарист. С. 5-32.

Из содерж.:

Н.В. Гоголь в Риме летом 1841 года. С. 34-120.

Коммент. С. 541-571.

Замечательное десятидетие.1838-1848. С. 121-367.

Коммент. С. 571-613.

[Указ. имен.]

Анненкова Е.И. Гоголь и Аксаковы (Лекция) / Министерство просвещения РСФСР, Ленинградский гос. пед. ин-т им. А.И. Герцена; отв. ред. Н.Н. Скатов. Л., 1983. 48 с.

Барбашова Л.В., Гуминский В.М. Гоголь и четыре урока «Миргорода» // Литературная учеба. М., 1983. № 2. С. 158-166.

Бароти Т. Традиция Данте и повесть Гоголя «Рим» // Studia Slavica Hung. T. 29. Br., 1983. C. 171-183.

Белинский В.Г. Статьи о Пушкине, Лермонтове, Гоголе. М.: Просвещение, 1983. 272 с.

Белинский В.Г. Взгляд на русскую литературу / Вступ. статья и коммент. А.С. Курилова. М.: Современник, 1983. 606 с. - (Библиотека «Любителям российской словесности»). Загл. вступ. статьи: Виссарион Белинский. С. 5-17.

О русской повести и повестях г. Гоголя. С. 192-150.

Взгляд на русскую литературу 1847 года. С. 518-598.

Коммент. С. 599-605.

Бердников Г. Творческое наследие Гоголя // Знамя. М., 1983. № 10. С. 204-221.

Бердников Г., Ким Ле Чун (Рехо). Наследие сатирика: Советско-японский симпозиум «Гоголь и современность» // Литературная газета. М., 1983. 26 октября. № 43. С. 2.

Бочаров И., Глушакова Н. Гоголь в Риме // Советский музей. М., 1983. С. 69-73.

Бретаниикая А.Л. «Нос» Д.Д. Шостаковича: Путеводитель. М.: Музыка, 1983. 95 с.

Букчин $C$. Народ, издревле нам родной. Белоруссия в русской классике. Похождения Чичикова в Минской губернии // Неман. 1983. № 5. С. 149-154.

Булгаков М., Каростин М. Необычайное происшествие, или Ревизор (по Гоголю): Сценарий / Публ. подгот. Г. Файман // Искусство кино. М., 1983. № 9. С. 112-134.

Файман Г. «В манере Гоголя»...». С. 106-109. 
Бурнамева С.A. Новая семантика гоголевских слов и выражений в произведениях В.И. Ленина // Русский язык в национальной школе. М., 1983. № 2. С. 14-18.

Волкова Л.П. Комедия «Игроки» в драматургической системе Н.В. Гоголя // Традиции и новаторство в русской литературе XIX века. Горький, 1983. С. 32-38.

Володина Ю.В. Жанровое своеобразие мемуаров П.В. Анненкова (Н.В. Станкевич, Н.В. Гоголь, А.И. Герцен) // Поэтика эпических жанров в русской литературе. Йошкар-Ола, 1983. C. $111-124$.

Boponaев B. Книги для Гоголя // Прометей: Историко-биографический альманах сер. «Жизнь замечательных людей». Т. 13 / Сост. В.И. Калугин. М.: Молодая гвардия, 1983. C. $128-142$.

Bрачу A. «Повесть о капитане Копейкине» в более старом переводе на румынский язык // Romanoslavica. 21 Buc., 1983. P. 349-357.

[Рассматривается перевод, выполненный Ch. D. Belinschi в 1910 г.].

Лозбэ М. Функциональный анализ художественного текста: «Шинель» Н.В. Гоголя (с учетом переводов на румынский язык) // Romanoslavica. 21 Buc., 1983. P. 399-417.

Гоголь и современность: Творческое наследие писателя в движении эпох. Киев: Вища школа, 1983. $150 \mathrm{c.}$

Содерж.:

Крутикова Н.Е. Великое братство. С. 9-30.

[Творчество Гоголя в контексте русско-украинских литературных взаимосвязей.]

Душечкина Е.В. «Тарас Бульба» в свете традиций древнерусской воинской повести. С. 30-34.

Михед П.В. Об истоках художественного мира Н.В. Гоголя (Н.В. Гоголь и В.Г. Нарежный). С. 35-41.

Пустовойт П.Г. Гоголевское начало в творчестве И.С. Тургенева. С. 41-49.

Карташова И.В. Об одной гоголевской традиции в творчестве Ф.М. Достоевского (Тема мечтателя). С. $49-56$.

Маевская Т.П. Гоголь и Короленко (Из опыта исследования преемственных и типологических связей). С. 57-61.

Евстафьева Е.Н. Н.В. Гоголь в жизни и творчестве Д.Н. Мамина-Сибиряка. С. 68-74.

Бобырь A.B. К вопросу о художественном наследии Гоголя в русской литературе начала XX века (Гоголь и Чириков). С. 75-78.

Абрамович С.Д. Способ художественного обобщения у Н.В. Гоголя. С. 98-105.

Самойленко Г.В. Гоголевские традиции в советской многонациональной литературе. С. 82-90.

Сохряков Ю.И. Н.В. Гоголь и современная реалистическая литература Запада. С. 91-97.

Абрамович С.Д. Способ художественного обобщения у Н.В. Гоголя. С. 98-105.

Михальский Е.Н. Мастерство психологического анализа в творчестве Н.В. Гоголя. С. 106-114.

[Рец.: Жаркевич Н. Досліджуючи класику // Радянское літературознавство. Киев, 1984. № 4. С. 68-69; Холодова Г.М. [Рец.] // Научные доклады высшей школы. Филологические науки. М., 1984. № 4. С. 87-88; Радецкая М. В современном прочтении // Вопросы литературы. М., 1984. № 3. С. 228-234.]

Гольденберг A.X. Фольклорные превращения в поэтике Гоголя // Русская литература и фольклорная традиция: межвузовский сб. научных трудов / Министерство просвещения РСФСР, Волгоградский гос. пед. ин-т им. А.С. Серафимовича; редкол.: Д.Н. Медриш (отв. ред.), А.М. Буланов, А.Х. Гольденберг и др. Волгоград, 1983. С. 53-63.

Гольденберг А.Х. Эволюция характеров в «Мертвых душах» и художественная традиция // Проблема традиций и новаторства в изучении и преподавании русской литературы (методические рекомендации для студентов). Горький, 1984. С. 19-20. 
Гончаров C.A. К вопросу об эволюции плутовского романа // III Всесоюзная научная конференция молодых ученых-филологов, посвященная 200-летию Георгиевского трактата. Тезисы докладов. Тбилиси, 1983. С. 62-63.

Гончаров С.A. О жанровом «контексте» «Мертвых душ» // Типологические категории в анализе литературного произведения как целого: сб. научных трудов / Кемеровский гос. ун-т; отв. ред. Н.Д. Тамарченко. Кемерово, 1983. С. 52-62.

Гуминский В.М. Гоголь и «Миргород» // В мире книг. М., 1983. № 4. С. 48-50.

Гуминский В.М. «Степной царь» (о пространстве прозы Н.В. Гоголя) // Литературная учеба. М., 1983. № 5. С. 189-198.

Гураль С.К. Психоаналитическое направление изучения творчества Н.В. Гоголя в современном американском литературоведении // Проблемы литературных жанров / Материалы IV научной межвузовской конференции 28 сентября - 1 октября 1982 г. Томск: Изд-во Томского ун-та, 1983. С. 51-52.

Гураль С.К. Творчество Н.В. Гоголя в современной американской критике (По материалам книг Т. Линдстром) («A Concise History of Russian Literature» и «Nicolay Gogol») // Проблемы метода и жанра. Томск, 1983. Вып. 10. С. 154-163.

Деревянко T. Из истории постановки фильма «Ревизор» / Сценарий М.А. Булгакова и М. С. Каростина // Искусство кино. 1983. № 9. С. 109-111.

Дилакторская О.Г. Повесть Н.В. Гоголя «Нос» (Бытовой факт как структурный элемент фантастики) // Вестник Ленинградского ун-та. Л., 1983. № 14. История, язык, литература. Вып. 3. С. 44-49.

Добринская Л.Б. Чисто русский анекдот // Добринская Л.Б. Рассказы из Пушкинского дома: Эссе. Л.: Детская литература, 1983. С. 155-175.

Есенков В. Совесть: Повесть о Гоголе / Предисл. С. Чупринина // Подъем. Воронеж, 1983. № 4. C. 17-115; № 5.

[Рец.: Кузнеиов Ф. В кривом зеркале // Новый мир. М., 1983. № 12. С. 227-241.]

Зарецкий B.A. Народная и авторская утопия в повести Н.В. Гоголя «Тарас Бульба» // Проблема автора в художественной литературе: межвузовский сб. научных трудов. Ижевск: Удмуртский гос. ун-т, 1983. С. 35-43.

Золотусский И.П. Очная ставка с памятью. М.: Современник, 1983. 288 с.

Из содерж.:

Уроки классики:

О прозе Гоголя. С. 141-158.

Гоголь о литературе. С. 158-178.

«Записки сумасшедшего» и «Северная пчела». С. 179-195.

Обманутый Хлестаков. С. 195-201.

Из дневника Зоила:

III:

[О стихотворении А. Вознесенского «Похороны Гоголя Николая Васильича» (Новый мир. М., 1974. № 1): C. 268-275.]

Искусство и художник в русской прозе первой половины XIX века: сб. произведений / Сост. и коммент. А.А. Карпова; вступ. статья В.М. Марковича. Л: Изд-во Ленинградского ун-та, 1983. 560 с.

Загл. вступ. статьи: Тема искусства в русской прозе эпохи романтизма.

История русской литературы XI-XX веков. Краткий очерк. М.: Наука, 1983. 479 с. 
Николаев П.А., Шаталов С.Е. Формирование критического реализма. «Натуральная школа». C. $196-216$.

[О Гоголе. С. 196-208 и др.]

Казарин В.П. Вопросы историзма в эстетике Гоголя и проблема эпического стиля повести «Тарас Бульба» // Художественное творчество и литературный процесс: сб. статей. Томск, 1983. Вып. 5. С. 115-124.

Карпенко А.И. О принципах смехового «ряженого» изображения в поэме Н.В. Гоголя «Мертвые души» // Вопросы русской литературы. Львов, 1983. Вып. 1(41). С. 120-129.

Карташова И.В. Гоголь и Вакенродер // Эстетика и творчество русских и зарубежных романтиков. Калинин, 1983. С. 55-71.

Кикачейшвили T. Обогащая родную литературу: Константинэ Гамсахурдия о творчестве Л. Толстого и Гоголя // Литературная Грузия. Тбилиси, 1983. № 5. С. 160-167.

Ковалев Вл. А. Поэтика Льва Толстого. Истоки. Традиции. М.: Изд-во Московского унта, 1983. $177 \mathrm{c}$.

Гл. 7: Гоголевское в поэтике Льва Толстого. С. 120-140.

Кривонос В.Ш. Биография Чичикова в составе «Мертвых душ» // Типологические категории в анализе произведения как целого. Кемерово, 1983. С. 98-105.

Кривонос В.Ш. Этическая функция призведения и авторские обращения к читателю в «Мертвых душах» Н.В. Гоголя // Функциональные аспекты изучения и преподавания литературы. Волгоград, 1983. С. 19-29.

Крупышев А.М. Спор о лиризме Н.В. Гоголя в «Мертвых душах» и «Заметки о журналах за октябрь 1855 года» Н.А. Некрасова // Н.А. Некрасов и русская литература XIX нач. XX века. Ярославль, 1983. Вып. 67. С. 17-28.

Кузьмин А.И. Маяковский и Гоголь // Русская речь. М., 1983. № 4. С. 18-22.

Куликова В.П. Отглагольные существительные со значением действия в русском литературном языке первой половины XIX века (На материале произведений А.С. Пушкина и Н.В. Гоголя) // Проблемы современной русской лексикологии. Калинин, 1983. С. 39-54.

Ланщиков А.П. Три Гоголя: По поводу книги И. Золотусского «Гоголь» // Ланщиков А.П. Чувство пути. М., 1983. С. 37-49.

Лебеденко Н.П. К вопросу о гоголевской традиции в творчестве А. Блока // Радянское литературознанство. 1983. № 4. С. 52-56.

Левищкий С.А. Очерки по истории русской философской и общественной мысли. Т. І. 2-е изд. Франкфурт-на-Майне: Посев, 1983. 216 с.

[А.М. Бухарев (в монашестве архимандрит Феодор) и Гоголь: С. 168-171].

Либер Л. Сравнительный анализ ценностного сознания гоголевских и чеховских персонажей // Hungaro-Slavica, 1983. Будапешт, 1983. № 1. С. 185-194.

Литература и нравственные проблемы современности: [сб. статей]: В 2 ч. / Под ред. П.А. Бугаенко и др. Ч. 2. Саратов: Изд-во Саратовского ун-та, 1983. 153 с.

Из содерж.:

Смирнова Е.А. Проблема авторской оценки и ее художественное решение в «Мертвых душах». C. $40-56$.

M. Р. Посвящается Гоголю // Вопросы литературы. М., 1983. № 12. С. 264-270.

[Отчет о третьем советско-японском симпозиуме (Токио, 1982)]. 
Манн Ю.В. У истоков русского романа // Вопросы литературы. М., 1983. № 5. С. 151-170. [Гоголь и В.Т. Нарежный.]

Медриш Д.Н. Метафорическая антитеза в фольклоре и литературе // Фольклор народов РСФСР. Уфа, 1983. С. 112-119.

[На материале русского фольклора и творчества Гоголя.]

Мельниченко О.Г. Жест и слово в «Вечерах на хуторе близ Диканьки» Н.В. Гоголя // Известия Воронежского гос. пед. ин-та. Воронеж, 1983. Т. 225. № 1. С. 89-106.

Мкртчян К.Л. «Записки сумасшедшего» и их армянский перевод // Вестник Ереванского ун-та. Общественные науки. Ереван, 1983. № 2. С. 175-185.

[О переводе А. Мазманяна (1954 г.)].

Мостовская Н.Н. Гоголь в восприятии Некрасова // Некрасовский сборник. Л., 1983. T. 8. C. $25-35$.

Нарежный B.T. Соч.: В 2 т. / Вступ. статья и примеч. Ю.В. Манна. М.: Художественная литература, 1983. Т. $1.623 \mathrm{c.}$

Загл. вступ. статьи: У истоков русского романа. С. 5-44.

[Гоголь и В.Т. Нарежный.]

Николаев П.А. Историзм в художественном творчестве и в литературоведении. М.: Изд-во Московского ун-та, 1983. 368 с.

Художественные открытия Н.В. Гоголя. С. 116-154.

Осокин В. Сожженная рукопись // Куранты. Историко-краеведческий альманах. М.: Московский рабочий, 1983. С. 187-193.

[О последних днях жизни Гоголя.]

От Пушкина до Чехова. Из русской прозы XIX века / Сост., предисл., справки о писателях А.М. Туркова. 2-е изд. М.: Русский язык, 1983. 447 с.

Из содерж.:

Н.В. Гоголь. С. 45-47. [На англ. яз.]

Нос: [повесть.] С. 48-71.

Паламарчук П. Неожиданная развязка. Вариант финальной сцены «Ревизора» // Неделя. М., 1983. № 20(1208). С. 12.

Паперный B.M. Андрей Белый и Гоголь: Статья вторая // Ученые записки / Тартусский гос. ун-т. 1983. Вып. 620. С. 85-98.

Пеньковский А.Б. Полежаев - Сопиков - Храповицкий // Русская речь. М., 1983. № 4. C. $124-134$.

[Происхождение названных фамилий в произведениях Гоголя.]

Пехтерев А. Невольно к этим берегам. Тула, 1983.

[О пребывании писателей (в частности Гоголя) в Калужском крае.]

Пистунова А.М. Книга книг. М.: Советская Россия, 1983. 256 с.

В гоголевской призме. С. 73-80.

[А.А. Агин - иллюстратор «Мертвых душ».]

Поддубная Р.Н. Тип героя и характер конфликта в повести Гоголя «Вий» // Вопросы художественной структуры произведений русской классики. Владимир, 1983. С. 61-80.

Поэтика реализма: межвузовский сб. / Куйбышевский гос. ун-т; редкол.: Л.А. Финк (отв. ред.) и др. Куйбышев: Куйбышевский гос. ун-т, 1983. 160 с.

Из содерж.:

Егоров И.В., Константиновская Е.Я. О формах выражения авторской позиции в «Мертвых душах» Н.В. Гоголя. С. 33-44. 
Кривонос В.Ш. Алогизм у Гоголя («Повесть о том, как поссорился Иван Иванович с Иваном Никифоровичем»). С. 44-52.

Свиясов Е.В. Гоголь и царская цензура // Русская литература. Л., 1983. № 2. С. 147-150.

Сенин А. Подсказано великим композитором (Опера Вайнберга «Портрет» по повести Гоголя) // Советская культура. М., 1983. 18 июня.

Славянские литературы: IX международный съезд славистов (Киев, сентябрь 1983 г.). Доклады советской делегации / Академия наук СССР. Отд. лит. и яз.; Советский комитет славистов. М.: Наука, 1983. 356 с.

Из содерж.:

Фридлендер Г.М. Гоголь и славянские литературы. С. 104-119.

Смирнова Е.А. О многосмысленности «Мертвых душ» // Контекст. 1982. М.: Наука, 1983. C. 164-191.

Структура литературного произведения: межвузовский сб. / Редкол.: И.К. Кузьмичев (отв. ред.), Т.Г. Боголепова, Н.И. Великая, С.И. Крившенко, В.И. Мельник. Владивосток: Изд-во Дальневосточного ун-та, 1983. 180 с.

\section{Из содерж.:}

Казарин В.П. Гоголь о творческом труде (По материалам писем писателя первой половины 30-х годов). С. 71-79.

Дилакторская О.Г. Мотив холода в «Петербургских повестях» Н.В. Гоголя. С. 79-86.

Турбин В.Н. Герои Гоголя: Книга для учащихся. М.: Просвещение, 1983. 127 с.: ил.

[Обсуждение книги под рубрикой «С разных точек зрения»: Казинщев А. Эффект концепции // Литературное обозрение. М., 1984. № 4. С. 40-43; Немзер А. Отметки не будет // Литературное обозрение. М., 1984. № 4. С. 44-47 [Полемика со статьей А. Казинцева]; заключение «От редакции». С. 47-48. Рец.: Киреев Р. Методу вопреки // Октябрь. М., 1984. № 6. С. 207-208.]

<Тургенев И.С.> И.С. Тургенев в воспоминаниях современников: В 2 т. Т. 2 / Подгот. текста С.М. Петрова и В.Г. Фридлянд; коммент. В.Г. Фридлянд. М.: Художественная литература, 1983. 557 с.: ил. - (Серия литературных мемуаров).

Коммент. С. 429-510.

[Указ. имен.]

Усачев С.В. Пришвин о Гоголе // Проблемы восприятия и оценки русской классической литературы. Ашхабад, 1983. С. 54-66.

Фридлендер Г.М. Литература в движении времени: историко-литературные и теоретические очерки. М.: Современник, 1983. 300 с.

О повести Гоголя «Рим». С. 104-112.

Фридман Н.B. Тема «маленького человека» в творчестве Пушкина и Гоголя // А.С. Пушкин и русская литература: сб. научных трудов / Министерство высшего и среднего специального образования РСФСР; Калининский гос. ун-т. Калинин, 1983. С. 32-50.

Челышев Б.Д. Имеют свое лицо... / Тираспольский гос. пед. ин-т им. Т.Г. Шевченко; отв. ред. В.А. Филатов. Кишинев: Штиинца, 1983. 207 с.: ил.

[В частности, разыскания книголюба о Гоголе.]

Чумак Т.М. Исторические реалии в повести Н.В. Гоголя «Страшная месть» // Вопросы русской литературы: республиканский межведомственный научный сб. Львов, 1983. Вып. 2(42). С. 79-86.

Шкловский В.Б. Избранное: В 2 т. М.: Художественная литература, 1983.

T. $1.637 \mathrm{c}$.

Гоголь С. 280-362.

T. 2. $640 \mathrm{c}$. 
Гоголь. Почему не дописаны «Мертвые души».

Gogol' e la sua opera: Colloquio italo-sovetico. Roma, 18-19 febbr. 1981. Roma: Accad. naz. dei Lincei, 1983. 183 p.: ill. - (Atti dei convegni Lincei / Accad. naz. dei Lincei; 58). На рус. и ит. яз. [Материалы итало-советской конференции (Рим, 18-19 февраля 1981 г.), посвященной творчеству Гоголя.]

Из содерж.:

Манн Ю. О жанровом феномене «Мертвых душ». Р. 155-163.

\section{4}

\section{ПРОИ З В Е ДЕНИЯ}

Вечера на хуторе близ Диканьки. Алма-Ата: Жазуши, 1984. 480 с.

Вечера на хуторе близ Диканьки. Миргород / Вступ. статья П. Николаева. М.: Художественная литература 1984. 463 с. - (Библиотека юношества).

Загл. вступ. статьи: Поэзия народной жизни. С. 3-11.

Приложение:

Ганц Кюхельгартен.

Вечера на хуторе близ Диканьки // Повести и рассказы писателей XIX - начала XX века / Вступ. слово М. Шолохова; редкол. М. Шолохов, М. Алексеев и др; сот. П. Николаева. М.: Художественная литература, 1984. С. 87-111.

Избранные сочинения: В 2 т. / Вступ. статья П. Николаева. М., 1984.

Загл. вступ. статьи: Художественные открытия Гоголя. С. 3-18.

Избранные соч.: В 2 т. / Вступ. статья П. Николаева; примеч. Ю. Манна. М.: Художественная литература, 1984. - (Библиотека классики. Русская литература).

Загл. вступ. статьи: Художественные открытия Гоголя. С. 5-16.

Т. 2.496 с.: ил.

Примеч. С. 483-494.

...К нам едет ревизор / Сост. Н.В. Колосова. 2-е изд. М.: Молодая гвардия, 1984. 448 с.: ил. - (Библиотека юношества).

Мертвые души / Предисл. П. Антокольского; Примеч. Ю. Манна; Ил. С. Тюнина. М.: Московский рабочий, 1984. 399 с.: ил.

Загл. предисл.: Мертвые души: поэма. С. 5-28.

Примеч. С. 358-366.

Мертвые души: поэма / Вступ. статья П. Антокольского; примеч. Ю. Манна; ил. С. Алимова. М.: Правда, 1984. 368 с.: ил.

Загл. вступ. статьи: Мертвые души: поэма. С. 5-28.

Приложение:

Повесть о капитане Копейкине (Редакция, разрешенная цензурой). С. 353-357.

Примеч. С. 358-366.

Молитва (К Тебе, о Матерь Пресвятая!..) // <Флоренский П.> Соль земли, то есть Сказание о жизни старца Гефсиманского скита иеромонаха аввы Исидора, собранное и по порядку изложенное недостойным сыном его духовным Павлом Флоренским монастыря Св.-Германовский Аляскинский монастырь. Платина (Калифорния), 1984. С. 37-38. Репринт с издания Свято-Троицкой Сергиевой лавры 1909 г.

Петербургские повести / Послесл. С.Г. Бочарова. М., 1984. 208 с.

Загл. послесл.: Петербургские повести Гоголя. С. 196-207.

Петербургские повести / Послесл. С.Г. Бочарова. Хабаровск: Книжное изд-во, 1984. 192 с.: ил. 
Загл. послесл.: Петербургские повести Гоголя. С. 179-192.

Повести / Сост., вступ. статья и коммент. В.М. Гуминского. М.: Книга, 1984.

Загл. вступ. статьи: Уроки Гоголя. С. 4-48.

Коммент. С. 385-409.

Повести / Сост., вступ. статья, примеч. Л.В. Барбашовой, В.М. Гуминского. М.: Книга, 1984. $478 \mathrm{c}$.

Повести / Вступ. статья С. Машинского. М.: Детская литература, 1984. 271 с.: ил.

Загл. вступ. статьи: Повести Гоголя. С. 5-27.

Повести. Драматические произведения. М.: Правда, 1984. 320 с.

Повести. Ревизор / Худож. С. Алимов. М.: Художественная литература, 1984. 336 с. (Классики и современники. Русская классическая литература).

Содерж:

Ночь перед Рождеством. С. 4-41.

Старосветские помещики. С. 42-61.

Тарас Бульба. С. 62-163.

Повесть о том, как поссорился Иван Иванович с Иваном Никифоровичем. С. 164-205.

Hoc. C. 206-227.

Шинель. С. 228-254.

Ревизор: комедия в пяти действиях. С. 255-332.

Повести. Ревизор. Женитьба. М.: Художественная литература, 1984. 526 с.: ил.

Ревизор, Мертвые души, Шинель; Салтыков-Щедрин М.Е. Господа Головлевы. Сказки. M., 1984.

Тюнькин К. Вершины русской сатиры. С. 3-42.

Собр. соч.: В 7 т. / Под общ. ред. С.И. Машинского и М.Б. Храпченко. М.: Художественная литература, 1984-1986.

[Текст печ. по изд.: Гоголь Н.В. Собр. соч.: В 7 т. М.: Хужожественная литература, 1976-1979.] Т. 1: Вечера на хуторе близ Диканьки / Коммент. А.В. Чичерина Н.Л. Степанова. М., 1984. 319 с. От издательства. С. 5-8.

Приложения:

Ганц Кюхельгартен. С. 203-237.

Две главы из малороссийской повести «Страшный кабан». С. 238-249.

Гетьман. С. 250-290.

Коммент. С. 291-318.

Чичерин А.В. [Сопроводит. статья:] Ранний Гоголь - романтик. С. 291-306.

Степанов Н.Л. [Коммент.] С. 306-318.

Т. 2. Миргород / Коммент. С.И. Машинского. М., 1984. 319 с.

Приложение:

Тарас Бульба [редакция «Миргорода» 1835 г.] С. 222-286.

Коммент. С. 287-318.

[Сопроводит. статья:] Миргород. С. 287-305.

Коммент. С. 305-318.

Т. 3. Повести / Коммент. Г.М. Фридлендера. М., 1984. 294 с.

Приложения:

Портрет (Редакция «Арабесок»). С. 211-249.

Ночи на вилле. С. 250-252.

Мелкие отрывки

Страшная рука. С. 252.

$<$ Фонарь умирал.> С. 252-254.

<Дождь был продолжительный.> С. 254-255.

$<$ Рудокопов.> С. 255. 
$<$ Семен Семенович Батюшек.> С. 256-257.

$<$ Девицы Чабловы.> С. 257.

Коммент. С. 258-293.

[Сопроводит. статья:] Повести. С. 258-274.

Коммент. С. 275-293.

Собр. соч.: В 8 т. / Под общ. ред. В.Р. Щербины. М.: Изд-во Правда, 1984. (Библиотека «Огонек». Отечественная классика).

Т. 1: Вечера на хуторе близ Диканьки / Вступ. статья В.Р. Щербины. Примеч. В.И. Сахарова. $382 \mathrm{c}$.

Загл. вступ. статьи: Н.В. Гоголь (1809-1852). С. 3-56.

Приложения:

Ганц Кюхельгартен. С. 272-308.

Две главы из малороссийской повести «Страшный кабан». С. 309-321.

Гетьман. С. 322-366.

Примеч. С. 367-381.

Т. 2: Миргород / Примеч. В. Гуминского. 319 с.

Приложение:

Тарас Бульба (Редакция «Миргорода» 1835 г.). С. 235-303.

Примеч. С. 304-318.

[Сопроводит. статья:] Миргород. С. 304-306.

Примеч. С. 306-381.

Т. 3. Повести / Примеч. М. Громова. 335 с.

Приложения:

Портрет <Редакция «Арабесок».> С. 226-268.

Ночи на вилле. С. 268-270.

Мелкие отрывки

Страшная рука. С. 270.

$<$ Фонарь умирал.> С. 270-272.

$<$ Дождь был продолжительный.> С. 272-274.

$<$ Рудокопов.> С. 274.

$<$ Семен Семенович Батюшек.> С. 274-275.

$<$ Девицы Чабловы.> С. 275.

Белинский В.Г. О русской повести и повестях г. Гоголя («Арабески» и Миргород»). C. $276-317$.

Примеч. С. 318-334.

Т. 4: Драматические произведения / Примеч. Г. Елизаветиной. 431 с.

Приложения:

Приложения к комедии «Ревизор»

1. «Ревизор» (Редакция первого издания, 1836 г.). С. 260-343.

2. Две сцены, выключенные как замедлявшие течение пьесы. С. 348-349.

3. Сцена, не внесенная автором в печатные издания «Ревизора». С. 328-329.

4. Отрывок из письма, писанного автором вскоре после первого представления «Ревизора»к одному литератору. С. 350-355.

5. Предуведомление для тех, которые пожелали бы сыграть как следует «Ревизора». С. 356-363.

6. Развязка «Ревизора». С. 364-375.

7. Вторая редакция окончания «Развязки «Ревизора». С. 376-381.

Владимир третьей степени. С. 382-389.

Альфред. С. 390-409.

Наброски драмы из украинской истории. С. 410-413.

Примеч. С. 414-430.

Т. 5. Мертвые души: Поэма: Том первый / Примеч. С. Машинского. 319 с.

Приложения:

Повесть о капитане Копейкине (Редакция, разрешенная цензурой). С. 250-255.

Предисловие ко второму изданию первого тома «Мертвых душ». С. 256-259. 
Черновые отрывки к отдельным главам. С. 260-307.

Примеч. С. 308-318.

Т. 6. Мертвые души. Том второй / Примеч. С. Машинского. 319 с.

[Приложение: ]

Короленко В.Г. Трагедия великого юмориста (Несколько мыслей о Гоголе). С. 260-310.

Примеч. С. 311-318.

Т. 7: Статьи. 1831-1847 / Примеч. Ю. Манна. 528 с.

Приложение:

Петербургская сцена в 1835-36 г. С. 467-478.

[Сопроводит. статья:] Манн Ю. Гоголь - критик и публицист. С. 479-499.

Примеч. С. 500-525.

Т. 8: Письма / Примеч. М. Громова. 399 с.

Приложение:

$<$ Письмо к> В.Г. Белинскому. Конец июля - начало августа 1847 г. С. 319-328.

Примеч. С. 329-360.

Алфавитный указатель имен и названий, встречающихся в статьях и письмах Н.В. Гоголя $($ т. 7,8$)$. С. 361-391. [Указ. имен аннотированный.]

Тарас Бульба / Вступ. статья, примеч., библиографические списки В.М. Гуминского; ил. А. Л. Костина. М.: Книга, 1984. 324 с.

Загл. вступ. статьи: «Тарас Бульба»: мир и книга. С. 5-46.

Примеч., библиографические списки. С. 295-324.

\section{Л И Т Е РАТ У РА}

Агаева И.И. «И как любил он - ненавидя!» К 175-летию со дня рождения Н.В. Гоголя // Русский язык и литература в азербайджанской школе. Баку, 1984. № 4. С. 11-21.

Алексанян Е. Искусство смеха. Гоголь и Паронян: проблемы типологии // Литературная Армения. Ереван, 1984. № 7. С. 79-89.

Алексеев М.П. Избранные труды. Пушкин. Сравнительно-исторические исследования / Отв. ред. Г.В. Степанов, В.Н. Баскаков. Л.: Наука, 1984.

[Указ. имен.]

Амберг Лоренцо. Литургия и храм у Гоголя // Dissertationes Slavicae. Slavistische Mitteilungen. Материалы и сообщения по славяноведению. Sectio Historiae Literarum. XVI. Szeged, 1984. C. 51-63.

Анненков П.В. Материалы для биографии А.С. Пушкина / Вступ. статья Г.М. Фридлендера; подгот. текста и коммент. А.А. Карпова. М.: Современник, 1984. 476 с. - (Библиотека «Любителям российской словесности. Из литературного наследия»).

Загл. вступ. статьи: Первая биография Пушкина. С. 5-31.

Коммент. С. 385-436.

[Указ. имен.]

Арват Н.Н. Структура текста повести Н.В. Гоголя «Шинель» // Русское языкознание. Киев, 1984. № 8. С. 116-124.

Арзуманова О.И., Кузнецова В.Г., Макарова Т.Н., Невский В.А. Музей-заповедник «Абрамцево»: Очерк-путеводитель. М.: Изобразительное искусство, 1984. 256 с.: ил, фот.

[Гоголь в Абрамцево.]

Асадуллаев С. Жизнь и обогащение традиции // Литературный Азербайджан. Баку, 1984. № 6. С. 108-114.

[Влияние Гоголя на творчество азербайджанских писателей.]

Асадуллаев С.Г. Н.В. Гоголь в Азербайджане // Русская литература. Л., 1984. № 4. С. 176-185. 
Бажин Е.Ф., Ганина Н.А., Корнеева Т.В. Описания лица в художественной литературе как проблема восприятия человека человеком // Вопросы психологии. М., 1984. № 2.

Балашов Н.И. Функции поэтической прозы в позднем творчестве Гоголя // Известия АН СССР. Сер. лит. и яз. М., 1984. Т. 43. № 5. С. 394-408.

Барская T. «...Был только в Крыму» // Советский Крым. Симферополь, 1984. 1 апреля. [Гоголь в Крыму.]

Белоусов А. Творческий путь Гоголя // Русский язык в эстонской школе. Таллин, 1984. № 2. C. 3-9.

Берковский Н. Заметки из архива (О Н.В. Гоголе) / Вступ. статья Г. Фридлендера; подгот. текста и примеч. Л. Виролайнен // Вопросы литературы. М., 1984. № 3. С. 108-125.

$<$ Блок A.A.> Библиотека А.А. Блока. Описание: В 2 кн. Кн. 1 / Библиотека Академии наук СССР: Институт русской литературы (Пушкинсий Дом) Академии наук СССР; сост. О.В. Миллер, Н.А. Колобоваой, С.Я. Вовиной; под ред. К.П. Лукирской. Л: Библиотека Академии наук СССР, 1984. 316 с.

[№ 309-310: Гоголь. С. 234.]

Блюм А. Гоголевский Петрушка: прототипы и последователи // В мире книг. М., 1984. № 4. C. 64 .

Блюмин Г. Последнее лето Гоголя // Ленинское знамя. 1984. 17 августа.

Богат E. В профиль и анфас. О «шукшинских сюжетах» в жизни // Литературная газета. М., 1984. № 34. С. 13.

[В.М. Шукшин и Гоголь.]

Боткин В.П. Литературная критика. Публицистика. Письма / Сост., вступ. статья и примеч. Б.Ф. Егорова. М.: Советская Россия, 1984. 320 с. - (Библиотека русской критики).

Загл. вступ. статьи: Боткин - критик и публицист. С. 3-22.

Примеч. С. 281-310.

Будагов Р.А. Стилистическое новаторство «Мертвых душ» Гоголя // Будагов Р.А. Писатели о языке и язык писателей. М., 1984. С. 95-117.

Букчин C.B. Похождения Чичикова в Минской губернии // Букчин С.В. ...Народ, издревле нам родной: Русские писатели и Белоруссия. Минск, 1984. С. 131-144.

Быков Р. Тайна давно известного / К 175-летию со дня рождения Н.В. Гоголя // Советская Россия. М., 1984. 1 апреля. № 77. С. 4.

Васильев К. Воспитатель и врач Гоголя // Вечерняя Одесса. Одесса, 1984. 19 февраля. [И.С. Орлай и его воспитательное значение.]

Васильев К.Г., Васильев К.К. И.С. Орлай и Н.В. Гоголь: К 175-летию со дня рождения Н.В. Гоголя // Советское здравоохранение. М., 1984. № 6. С. 69-71.

Век нынешний и век минувший // В мире книг. М., 1984. № 4. С. 38-39; 42-44.

[Иллюстраторы произведений Гоголя.]

Великий художник слова: К 175-летию со дня рождения Н.В. Гоголя // Литературная газета. М., 1984. 4 апреля. № 14. С. 2.

[Авторы статей: С. Залыгин, Н. Скатов, В. Кирилюк.]

Венок Н.В. Гоголю: Гоголь и время / Сост. Б.Н. Левин; худож. В.А. Рияка. Харьков: Прапор, 1984. 152 с.: 8 л. ил. На рус. и укр. яз.

Из содерж.: 
Гончар О. Гоголевскими шляхами. С. 11-12.

Цюпа И. Гоголевщина. С. 24-31.

Михальский Е.Н., Самойленко Г.В. Гоголь в Нежине. С. 51-54.

Лобуреи В.Е. Гоголевские образы в трудах В.И. Ленина. С. 101-106.

Крутикова Н.Е. Гоголь и украинская литература. С. 114-124.

Золотусский И. Гоголь в Риме.

Гончар О. Гоголь и Украина. С. 138-150.

[Рец.: Паламарчук П. Гоголь и наше время // Дружба народов. М., 1986. № 6. С. 262-263.]

Виролайнен М.Н. Конференция, посвященная 175-летию со дня рождения Н.В. Гоголя / Ленинград, 23-24 апреля 1984 г. // Русская литература. Л., 1984. № 4. С. 223-226.

Вишневская И. Неюбилейный Гоголь // Советская культура. М., 1984. 29 марта. С. 4.

Вишневская И. Перечитаем Гоголя! // Театр. М., 1984. № 3. С. 17-21.

Власенко Л. По гоголевским местам. «Москва - моя родина» // Строительство и архитектура Москвы. М., 1984. № 7. С. 27.

Вопросы русской литературы. Вып. 2(44): республиканский межведомственный научный сб. / Министерство высшего и среднего специального образования УССР; Черновицкий гос. ун-т; редкол.: Н.В. Николаев (отв. ред.), Д.М. Степанюк (отв. секр.) и др. Львов: Издво при Львовском гос. ун-те издательского объединения «Вища школа», 1984. 119 с.

Из содерж.:

Губарев И.М. О художественном психологизме Н.В. Гоголя (На материале его высказываний). C. 71-77.

Краевская Г.М. Традиции Н.В. Гоголя в творчестве раннего А.И. Куприна. С. 78-84.

Полек В.T. Сочинения Н.В. Гоголя на Западной Украине. С. 84-91.

Воропаев В.А. К истории публикации «Мертвых душ» // Вестник Московского ун-та. Сер. 9. Филология. М., 1984. № 3. С. 10-13.

Bоропаев B. Судьба рукописи. Новые известия о втором томе «Мертвых душ» // Литературная учеба. М., 1984. № 3. С. 167-171.

Bоропаев B. «...Я совершу свой путь...» К 175-летию со дня рождения Н.В. Гоголя // Библиотекарь. М., 1984. № 4. С. 49-52.

Воропаев В. Загадки гоголевских библиотек // В мире книг. М., 1984. № 4. С. 65-67.

Bоропаев B. Гражданин земли Русской // Советский воин. М., 1984. № 7. Апрель. C. $22-23$.

Вулих Н.В. Античные мотивы и образы повести Гоголя «Тарас Бульба» // Русская литература. Л., 1984. № 1. С. 143-153.

Bbхходиев П.С. Преемственность гуманизма (Гоголь и Пришвин) // Русская литература. Л., 1984. № 4. С. 3-17.

Вяземский П.А. Эстетика и литературная критика / Сост., подгот. текстов, вступ. статья и коммент. Л.В. Дерюгиной. М.: Искусство, 1984. 458 с. - (История эстетики в памятниках и документах).

Загл. вступ. статьи: Эстетические взгляды П.А. Вяземского. С. 7-42.

Из содерж.:

«Ревизор». Комедия, соч. Н. Гоголя. С.-Петербург, 1836. С. 142-154.

Коммент. С. 411-412.

[Впервые: Современник. 1836. Т. 2. С. 285-309.] 
Языков и Гоголь. С. 162-187.

Коммент. С. 414-417.

[Впервые: Санкт-Петербургские Ведомости. 1847. 24 и 25 апреля. № 90, 91.]

Современные темы, или Канва для журнальных статей. С. 271-276.

[Гоголь в журнальной критике.]

[Указ. имен.]

Bыходиев П.С. Преемственность гуманизма: Гоголь и Пришвин // Русская литература. Л., 1984. № 4. С. 3-17.

Гальиеева Р., Роднянская И., Бибихин В. «Обескураживающая фигура» (Н.В. Гоголь в зеркале западной славистики // Вопросы литературы. М., 1984. № 3. С. 126-161.

[Обзор работ 1950-1980-х гг.]

[См. также сб. Гоголь: История и современность. М., 1985.]

Гладыпшева Л.А. Птица-тройка // Русская речь. М., 1984. № 2. С. 26-29.

Гоголевские места на Украине. Фотоальбом / Сост. и вступ. статья Н.А. Хоцкого; фото И.А. Гильбо; худож. Н.Ю. Слепцова. Киев: Мыстэцтво, 1984. 96 с. На рус. и укр. яз.

$<$ Гоголь Н.В>. Н.В. Гоголь и литература народов СССР: Библиографический указатель / Нежинский гос. пед. ин-т им. Н.В. Гоголя; сост. Г.В. Самойленко, Е.Н. Михальский; предисл. Г.В. Самойленко]. Нежин, 1984. 147 с.

Гончар Н.А. Д.Демирчян - переводчик «Мертвых душ» Н.Гоголя (К вопросу о «психологии», технике и эстетике художественного перевода) // Литературные связи. Ереван, 1984. T. 4. C. 95-137.

Гончар-Ханджян Н.А. Во власти бессмертного голоса (О ритме в поэме «Мертвые души» и об отражении его в армянском переводе Д. Демирчяна) // Вестник Ереванского ун-та. Общественные науки. Ереван, 1984. № 1. С. 45-56.

Горелов А.Е. Очерки о русских писателях: Избранное. 4-е изд. Л.: Советский писатель: Ленинградское отделение, 1984. 607 с.

Именем живых: Н.В. Гоголь. С. 82-107.

Грудинина И. Два русских гения. К 175-летию со дня рождения Н.В. Гоголя // Нева. Л., 1984. № 4. С. 172-175.

[О дружбе Гоголя и А.А. Иванова.]

Гужанов С.И. Сравнение как средство сатирического изображения действительности в поэме Н.В. Гоголя «Мертвые души» // Русское языкознание. Киев, 1984. Вып. 8. С. 129-136.

Гураль С.К. Американское литературоведение о проблеме автора и повествователя в «Вечерах на хуторе близ Диканьки» Н.В. Гоголя // Литература, журналистика и политическая жизнь в США. М., 1984. С. 66-86.

Дзюба A.А. Гоголь и музыка // Русский язык и литература в средних учебных заведениях УССР. Киев, 1984. № 2. С. 21-27.

Дилакторская О.Г. Фантастическое в повести Н.В. Гоголя «Нос» // Русская литература. Л., 1984. № 1. С. 153-166.

Дмитриев Ю.А. Малый театр, 1917-1941 гг. М.: Искусство, 1984. 381 с.

[Указ. имен.]

Довгаль И.Ф., Литвин Н.О. Великосорочинский литературно-мемориальный музей Н.В. Гоголя: Путеводитель. 5-е изд., перераб. и доп. Харьков: Прапор, 1984. 62 с.: ил. 
Дранкова И.Г. Гоголь и Вогюэ (К 175-летию со дня рождения Н.В. Гоголя // Проблемы истории культуры, литературы, социально-экономической мысли. Саратов, 1984. С. 44-51.

Ерохин А. Живые «Мертвые души»: Гоголевская поэма в иллюстрациях Виталия Горяева // Литературная Россия. М., 1984. 30 марта. № 14. С. 20.

Жулинский Н. Талант яркий и неисчерпаемый: К 175 -летию со дня рождения Н.В. Гоголя // Под знаменем ленинизма. Киев, 1984. № 5. С. 71-72.

Записки русской академической группы в США: [ежегодный журнал общества «Русская академическая группа в США»]. Т. 17 / Ред. Н.А. Жернакова. New-York, 1984. 321 с. На рус. и англ. яз.

Из содерж.:

Юрьева 3., Филипn В. О поэтике страха в повести Гоголя «Вий». С. 3-21.

Жернакова Н. «Портрет» Гоголя в двух редакциях. С. 23-47.

Каухчишвили Н. О художественных приемах у Гоголя. С. 49-67.

Tеррас B. «Шинель» Гоголя в критике молодого Достоевского. С. 75-81.

Натова Н. Михаил Булгаков и Гоголь: Опыт сопоставительного анализа. С. 83-114.

Крупич В. Гоголь и Аполлон Григорьев. С. 133-141.

Полтораикий Н. И.А. Ильин о Гоголе. С. 143-170.

[Изложение лекции «Гоголь, великий сатирик, романтик и философ жизни» (1944).]

[Перепечатано: Полтораикий Н. И.А. Ильин: Жизнь, труды, мировоззрение: сб. статей. Без м. изд. Эрмитаж, 1989. С. 77-98.]

Иванов-Натов А. Новое прочтение «Выбранных мест из переписки с друзьями». С. 171-191.

Климов Е. Иллюстрации русских художников XX века к произведениям Н.В. Гоголя. C. $193-215$.

[Откл.: Бахрах А. Гоголь в новых отражениях // Новое русское слово. Нью-Йорк, 1985. 4 августа. С. 5.]

Зарубежное литературоведение 70-х годов. Направления, тенденции, проблемы. М.: Наука, 1984.

Заславский И. Гоголь в украинских переводах // Радуга. Киев, 1984. № 4. С. 161-164.

Золотусский И. Блок и Гоголь // Atti del symposium «Aleksandr Blok». Milano - Gargnano del Garda 6-11 settembre 1981. Milano, 1984. P. 711-726.

Золотусский И. Высокое благородство сердца // Огонек. М., 1984. № 14. С. 14-16.

[К 175-летию со дня рождения Гоголя.]

Золотусский И.П. Гоголь. Изд. 2-е, испр. и доп. М.: Молодая гвардия, 1984 / Сер. ЖЗЛ. 527 с. [Рец.: Мамлеев Ю. Бессмертие мертвых душ // Континент. Мюнхен, 1986. № 47. С. 404-408.]

Золотусский И. Гоголь в Москве // Литературная Россия. М., 1984. 30 марта. № 14. С. 6-7.

Золотусский И. Горизонт без конца: К 175-летию со дня рождения Н.В. Гоголя // Новый мир. М., 1984. № 4. С. 238-248.

Золотусский И. Еще о «Ревизоре» // Современная драматургия. М., 1984. № 1. С. 260-267.

Золотусский И. Здесь создавались «Мертвые души» // Юность. М., 1984. № 4. С. 97-100.

Золотусский И. Песнь о товариществе: К 175-летию со дня рождения Н.В. Гоголя // Москва. М., 1984. № 4. С. 181-187.

Золотусский И.П. По следам Гоголя. М.: Детская литература, 1984. 191 с.: ил. - (По дорогим местам). 
[Рец.: Клименко В. Путешествие за словом // Москва. М., 1986. № 1. С. 202-203.]

Золотусский И. Смех Гоголя // Октябрь. М., 1984. № 4. С. 195-200.

Ильинский О. К юбилею Гоголя // Русское возрождение. Нью-Йорк; Москва; Париж, 1984. № 27/28. C. 141-161.

[Отклик на статью И. Золотусского «Песнь о товариществе» // Новый мир. М., 1984.]

Инфантьев Б., Лосев А. Гоголевское притяжение // Даугава. Рига, 1984. № 4. С. 109-114. [Влияние Гоголя на латышскую литературу.]

Искрин М. Тайна одного стихотворения // Московская правда. М., 1984. 6 июня.

[По поводу стихотворения Пушкина «С Гомером долго ты беседовал один...».]

Казарин В.П. А.С. Пушкин и творческая история повести Н.В. Гоголя «Тарас Бульба» // Вопросы русской литературы. Львов, 1981. Вып. 1. С. 54-61.

Казарин В.П. Романтическая традиция в «Мертвых душах» // Русския язык и литература в средних учебных заведениях УССР. Киев, 1984. № 3. С. 12-16.

Казарин В.П. Типология героя в русской литературе XIX века: Учебное пособие для студентов-иностранцев / Министерство высшего и среднего специального образования УССР; Симферопольский гос. ун-т им. М.В. Фрунзе. Симферополь: Симферопольский гос. ун-т, $1984.87 \mathrm{c}$.

Гл. 3: Поэма Гоголя «Мертвые души». С. 70-83.

Казинцев А., Казинцева Н. Автор двух поэм (К 175-летию со дня рождения Н.В. Гоголя) // Поэзия. М., 1984. № 40. С. 106-117.

Казинцева Н., Казинцев $А$. Автор двух поэм: О поэтическом начале в художественном мышлении Гоголя // Литература в школе. М., 1984. № 1. С. 20-26.

Капустин В. Гений нашей литературы // Южная Правда. Николаев, 1984. 1 апреля. [К 175-летию со дня рождения Гоголя.]

Карташова И.В. «Портрет» Н.В. Гоголя и эстетические принципы В.Г. Вакенродера // Научные доклады высшей школы. Филологические науки. М., 1984. № 4. С. 69-73.

Катаев B. Возвращаясь к Гоголю / Беседу вел А. Кузнецов // Вопросы литературы. М., 1984. № 3. С. 88-107.

Кирай Д. К проблеме авторской точки наблюдения в повествовательной концепции текста Пушкина, Гоголя, Достоевского и Толстого // Studia russica. Br., 1984. P. 141-158.

Клименко В. Енотовая шуба: Петербург и «Петербургские повести» Н.В. Гоголя // Литературная Россия. М., 1984. 30 марта. № 14. С. 17.

Ковач A. Модель инерции мышления в «Шинели» Гоголя // Studia Russica. 7. Budapest, 1984. Р. 159-171.

Колоколова Л.И. Лексико-семантические источники антропонимии в повести Н.В. Гоголя «Тарас Бульба» // Русское языкознание. Киев, 1984. Вып. 8. С. 124-129.

Кошелев В.А. Эстетические и литературные воззрения русских славянофилов (18401850-е годы). Л.: Наука. Ленинградское отделение, 1984. 196 с.

«Мертвые души» Н.В. Гоголя в славянофильском истолковании. С. 106-143.

Краюхин С. Родственница Пушкина и Гоголя // Неделя. М., 1984. № 22. 
Кубарев E.M. Формирование структуры художественного текста в процессе работы Н.В. Гоголя над комедией «Ревизор» (На примере отражения психического состояния персонажа в аффектической речи // Формирование семантики и структуры художественного текста: межвузовский сб. научных трудов / Куйбышев. гос. пед. ин-т им. В.В. Куйбышева; редкол.: М.Н. Везерова (отв. ред.) и др. Куйбышев, 1984. С. 70-96.

Кузнецова Н. Бессмертие Гоголя // Культура и жизнь. М., 1984. № 7. С. 32.

Лазарева A. О рефлексивности гоголевского смеха // Эстетические проблемы художественного творчества. М., 1984. С. 41-48.

Лазарева А. Проблема субъекта творчества в эстетике Гоголя // Историко-методологические проьлемы эстетического познания. М., 1984. С. 51-58.

Лазарева А.Н. Этические искания в творчестве Н.В. Гоголя // Факторы и механизмы динамики культуры. М., 1984.

Лесков А.Н. Жизнь Николая Лескова: По его личным, семейным и несемейным записям и памятям: В 2 т. М.: Художественная литература, 1984. - (Литературные мемуары).

Т. 1 / Вступ. статья, подгот текста, коммент. А. Горелова. 479 с.

Загл. вступ. статьи: Книга сына об отце. С. 5-30.

Коммент. 416-477.

Т. 2 / Подгот. текста и коммент. В. Туниманова и Н. Сухачева. 607 с.

Коммент. 505-563.

[Указ. имен.]

Лихачев Д.С. Литература - реальность - литература. Л.: Советский писатель, 1984. 271 с. Из содерж.:

Социальные корни типа Манилова. С. 31-43.

Ахматова и Гоголь. С. $155-160$.

Лобанов М. Вечное слово: К 175-летию со дня рождения Н.В. Гоголя // Молодая гвардия. М., 1984. № 4. С. 237-248.

Лобашкова А.И. Эстетические искания в творчестве Н.В. Гоголя // Факторы и механизмы динамики культуры / Академия наук СССР, Институт философии; редкол.: А.И. Арнольдов (отв. ред.) и др. М.: ИФАН, 1984. С. 55-64.

Лурье С. Гоголь, Башмачкин и другие / Послесл. Е. Невзглядовой // Аврора. Л., 1984. № 4. C. 115-122.

Макогоненко Г. Принадлежит России: К 175-летию со дня рождения Н.В. Гоголя // Звезда. Л., 1984. № 4. С. 154-171.

Манн Ю.В. В поисках живой души: «Мертвые души»: Писатель - критика - читатель. М.: Книга, 1984. 415 с. - (Судьбы книг).

[Рец.: Залысиин С. «Гоголевский вопрос» // Литературная газета. М., 1985. 16 января. № 3. С. 6; Немзер A. Счастливые поиски // Литературное обозрение. М., 1985. № 3. С. 61-63; Koehler L. [Rev.] // Slavic and East European Journal. Tucson, 1986. Vol. 30. № 3. P. 442-444; Бакчи Д. // Studia Slavica. Budapest, 1987. T. 33, fasc. 1/4. C. 389-391.]

Манн Ю.В. Всемирная известность // Книжное обозрение. М., 1984. № 13. С. 8. [К 175-летию со дня рождения Гоголя.]

Манн Ю.В. Гоголь Н.В. Язык его произведений // Энциклопедический словарь юного филолога (Языкознание). М., 1984. С.64-68. 
Манн Ю.В. Гоголь в контексте эстетических споров (Полемика В.Г. Белинского с Константином Аксаковым) // Вопросы философии. М., 1984. № 3. С. 111-119.

[К 175-летию со дня рождения Гоголя.]

Манн Ю. Гоголь на Пьяцце Сан-Джованни // Дружба народов. М., 1984. № 5. С. 259-263.

Манн Ю. Как построены «Мертвые души» // Литературная учеба. М., 1984. № 3. С. 157-166.

Манн Ю. Как построены «Мертвые души» // Soviet Literature. M., 1984. № 4. С. 164-176.

Манн Ю. «Показать всю Русь...»: У истоков поэмы «Мертвые души» // Литературное обозрение. М., 1984. № 4. С. 31-39.

Манн Ю.В. Полемика Белинского с Константином Аксаковым о «Мертвых душах» Гоголя // Zeitschrift für Slawistic. Berlin, 1984. Bd. 29. H. 4. S. 535-545.

Марченко Н. Мемории из портфеля: К 175-летию со дня рождения Н.В. Гоголя // Советский музей. М., 1984. № 2. С. 28-29, 45.

Марченко Н., Малиновская E. «По знакомству моему с художниками...» Рисунки Н.В. Гоголя и К.К. Павловой // В мире книг. М., 1984. № 4. С. 41-47.

Матвеев Б.И. Живое и меткое слово Н.В. Гоголя // Русская речь. М., 1984. № 2. С. 21-25.

Мацкин А.П. На темы Гоголя: Театральные очерки / Послесл. Е.И. Поляковой. М.: Искусство, 1984. 375 с.: ил. 16 л.

Загл. послесл.: На темы прочитанной книги. С. 368-374.

Содерж: :

От автора. С. 3-4.

Михаил Чехов - Хлестаков. 1921-1927. С. 5-62.

Мейерхольд. Как создавался «Ревизор» 1926. С. 63-213.

Станиславский. Скрещение идей и судеб в «Мертвых душах». 1932. С. 214-367.

[Рец.: Манн Ю. // Новый мир. М., 1985. № 7. С. 266-267; Смелянский А. На гоголевском перекрестке // Вопросы литературы. М., 1985. № 3. С. 242-249; Борщаговский А. И не только театральная история // Театр. М., 1985. № 4. С. 158-160; Кириллов А. Сценическое освоение классики // Нева. Л., 1985. № 9. С. 166-167.]

Мильдон В. Мир вещей у Гоголя // Декоративное искусство СССР. М., 1984. № 4. С. 34-39.

Михалков С. Слово о Гоголе // Литературная Россия. М., 1984. 6 апреля. № 15. С. 4.

Мкртчян $K$. «Невский проспект» - «всеобщая коммуникация» петербургских повестей [Н.В. Гоголя] // Литературная Армения. Ереван, 1984. № 7. С. 89-98.

Мкртчян К.Л. Петербургские повести Н.В. Гоголя в армянских переводах: Прочтение оригинала как переводческая проблема. Ереван: Изд-во Ереванского ун-та, 1984. 139 с.

[Рец.: Тухарели Д. Проблема оригинала и перевода // Советакан граканутюн. Ереван, 1985. № 8. C. 135-137; Григорян A. Прочтение оригинала как переводческая проблема // Литературная Армения. Ереван, 1985. № 11. С. 105-108.]

Мовчан П. От свитки до шинели: К 175-летию со дня рождения Н.В. Гоголя // Дружба народов. М., 1984. № 4. С. 231-239.

Молева Н. Свет добра и справедливости: К 175-летию со дня рождения Н.В. Гоголя // Комсомольская правда. М., 1984. 31 марта.

[О молодых годах Гоголя и начале его творческого пути.]

Моргун Ф.Т. В отчем доме Н.В. Гоголя // Радуга. Киев, 1984. № 8. С. 103-110. 
[О заповеднике-музее на Полтавщине в селе Гоголево (Васильевке).]

Музей-заповедник «Абрамцево»: Очерк-путеводитель / Авт.: О.И. Арзуманова, А.Г. Кузнецова, Т.Н. Макарова, В.А. Невский. М.: Изобразительное искусство, 1984. 256 с.: ил.

[О Гоголе: С. 34-56 и др.]

Немзер А.С. Н.В. Гоголь // Памятные книжные даты. М., 1984. С. 87-89.

Никифоров B. «Ему есть куда поглядеться»: К 175-летию со дня рождения Н.В. Гоголя // Нева. Л., 1984. № 4. С. 185-189.

Николаев Д.П. Пасичник Рудый Панько и вопрос о социальных истоках сатиры Гоголя // Вестник Московского ун-та. Сер. 9. Филология. М., 1984. № 3. С. 3-9.

Николаев Д.П. Сатира Гоголя. М.: Художественная литература, 1984. 367 с.: 9 л. ил.

[Рец.: Дмитренко С. Действенность смеха // Новый мир. М., 1986. № 9. С. 263-264; Радеикая М. Сатира Гоголя в сегодняшнем прочтении // Вопросы литературы. М., 1986. № 3. С. 238-243.

Новиков Л.А. Художественное слово Гоголя (Стилистический анализ «Повести о том, как поссорился Иван Иванович с Иваном Никифоровичем») // Русский язык в школе. М., 1984. № 1. C. 48-55.

Осокин В. Ожившая статуя / [Послесл. В. Погребного]. М.: Молодая гвардия, 1984. 190 с.: ил. - (Сер. Загадки отечественной культуры).

Из содерж.:

Аксаков и Гоголь. С. 104-110.

Плюшкин... в таверне (Н. Гоголь). С. 110-113.

Павлова И.Б. Юбилейная научная конференция, посвященная 175-летию со дня рождения Н.В. Гоголя / Москва, 29-30 марта 1984 г. // Известия АН СССР. Сер. лит. и яз. М., 1984. T. 43. № 5. С. 475-477.

Паламарчук П. «Высокая комедия»: «Ревизор» и дополнения к «Ревизору» // Литература в школе. М., 1984. № 5. С. 62-64.

Паламарчук П. Ключ к «Ревизору» // Советская литература. М., 1984. № 4.

Парамонов Б. К юбилею Гоголя // Панорама. Лос Анжелес, 1984. 27 апреля - 4 мая. № 159. C. 10 .

[К 175-летию со дня рождения.]

Пенская Е.Н. Н.В. Гоголь // Альманах библиофила. М., 1984. № 2.

[К 175-летию со дня рождения.]

Петров А. Дом Гоголя // Нева. Л., 1984. № 4. С. 189-192.

Петров Б. За коляской Чичикова // Советская Россия. М., 1984. 23 марта. С. 4.

[Беседа с художником-графиком Сергеем Алимовым.]

Попов В. Великий подвиг любви к России: Заметки литературоведа // Кубань. Краснодар, 1985. № 12. С. 76-82.

Прийма Ф.Я. Гоголь и народная Россия // Русская литература. Л., 1984. № 2. С 3-27.

$<$ Пришвин М.> Пришвин о Гоголе: Из дневников разных лет / Публ. и примеч. Л. Рязановой // Литературная учеба. М., 1984. № 3. С. 172-177.

Прожогин Н. Альбомная страница, или Стихотворение в прозе // Советская культура, М., 1984. 24 марта.

[См. также: Прожогин Н. Под миртами Италии прекрасной. М., 1988. С. 52-60.] 
См. также Жовтис 1973.]

Пьнзару С. Гоголь в предоктябрьской Бессарабии // Кодры. Кишинев, 1984. № 12. С. 144-147.

Раков Ю. Где жил Башмачкин // Ленинградская правда. Л., 1984. 28 июля.

Раковская Н.М. Г. Плеханов о месте и роли Н. Гоголя в историко-литературной концепции В.Г. Белинского // Проблемы поэтики и истории литературы. Одесса, 1984. С. 128-138.

Рехо К. Гоголь в Японии // Русская речь. М., 1984. № 2. С. 30-38.

Рехо К. Японо-советский симпозиум «Гоголь и современность»/ Токио, апрель 1983 г. // Япония. 1983: Ежегодник. М., 1984. С. 284-288.

Сажин В. На пороге. Из архивных разысканий о Н.В. Гоголе // Звезда. 1984. № 4. С. 177-179.

Сахаров В. Романтики и реалисты // Подъем. Воронеж, 1984. № 6. С. 119-121.

[О творческом содружестве Гоголя и князя В.Ф. Одоевского.]

Сахаров В. Под сенью дружных муз: О русских писателях-романтиках. М.: Художественная литература 1984. 295 с.

[Гоголь и В.А. Жуковский.]

Семенов Р. Афанасий Иванович и Аграфена Максимовна, или Образ семьянина у Гоголя и Платонова // Литературная учеба. М., 1985. № 6. С. 183-193.

Сергиева Н.Н. Характеры и ситуации в повести Н.В. Гоголя «Нос» // Проблемы поэтики и истории литературы. Одесса, 1984. С. 147-157.

Скатов Н. Иван Александрович Хлестаков и другие // Звезда. Л., 1984. № 4. С. 172-176. [Анализ комедии «Ревизор» с точки зрения ее сценической интерпретации.]

Смелянский $A$. Жизнь во времени. Заметки о телефильме «Мертвые души» // Комсомольская правда. М., 1984. 2 декабря. С. 4.

[О телесериале М. Швейцера.]

Современные зарубежные исследования творчества Н.В. Гоголя: сб. научно-аналитических обзоров. М., 1984. (ИНИОН). 154 с.

Из содерж.

Красавченко T.H. Реальность и вымысел у Гоголя (взгляд английской литературной критики). C. 63-92.

Степанов В.Г. Критика оценки повестей Н.В. Гоголя буржуазным литературоведением Англии и США 40-х - 60-х годов ХХ века: И. Перри, В. Набоков, В. Эрлих // Функциональное и системно-типологическое изучение языка и литературы. М., 1984. С. 206-213.

Степанов Г. «Ваял, а не писал» // Литературная Россия. М., 1984. 30 марта. № 14. С. 19. [С.Н. Сергеев-Ценский о Гоголе.]

Страницы сожженного тома // Известия. 1984. 2 апреля. № 93. С. 6.

[О втором томе «Мертвых душ» Гоголя.]

Страхов Н.Н. Литературная критика / Вступ. статья, сост. Н.Н. Скатова; примеч. Н.Н. Скатова и В.А. Котельникова. М.: Современник, 1984. 431 с. - (Библиотека «Любителям российской словесности»).

Загл. вступ. статьи: Н.Н. Страхов (1828-1896). С. 5-43.

Коммент. С. 407-426.

[Указ. имен.]

Сугай Л.А. Идейные споры о наследии Н.В. Гоголя в конце XIX - начале XX века // Научные доклады высшей школы. Филологические науки. М., 1984. № 4. С. 3-10. 
Сугай Л.А. Русская критика XIX века и трактовка Гоголя символистами // Проблема традиций и новаторства в изучении и преподавании советской литературы. Горький: ГГПИ [Горьковский гос. пед. ин-т им. М. Горького], 1984. С. 18-19.

Султанова Г. Муза, открывшая миры. Баку: Язычы, 1984. 183 с. - (Литературные связи). [Сопоставительный анализ произведений русской литературы (в том числе Гоголя) и их переводов на азербайджанский язык.]

Сурмило В. Встреча в Венеции // Литературная Россия. М., 1984. 13 апреля.

[Отрывок из воспоминаний И.К. Айвазовского о встрече с Гоголем.]

Тезисы докладов вторых Гоголевских чтений, посвященных 175-летию со дня рождения писателя / Министерство просвещения УССР, Полтавский гос. пед. ин-т им. В.Г. Короленко и др.; редкол.: Н.Е. Крутикова, Т.П. Маевская, Н.В. Хоменко и др.; Полтава, 1984. 212 с.

Содерж.:

Горобеи И.Е. Гоголь и современная Полтавщина. С. 3-4.

Зязюн И.А. О принципах театральной эстетики Н.В. Гоголя. С. 4-6.

Фридлендер Г.М. Истоки гоголевского реализма. С. 6-7.

Матвиенко П.И. Полтавщина в творчестве Н.В. Гоголя. С. 7-8.

Лобуреи В.Е. Гоголевские образы в теоретическом наследии В.И. Ленина. С. 8-10.

Кулешов В.И. О методологии изучения наследия Н.В. Гоголя. С. 10-11.

Яценко М.Т. Гоголь и украинский романтизм. С. 11-12.

Прийма Ф.Я. Гоголь и Белинский. С. 13-14.

Вайнгорт Л.С. Заповедник-музей Н.В. Гоголя на Полтавщине. С. 14-15.

Хоменко Н.В. Идейное утверждение и отрицание в творчестве Гоголя. С. 15-16.

Борщевский Ф.М. Кантемир, Фонвизин, Гоголь - преемственность и новаторство. С. 16-17.

Троиикий В.Ю. Гоголь и русская предромантическая проза. С. 18.

Козлова М.И. На пути движения к реализму (Н.В. Гоголь и В.Т. Нарежный). С. 19-20.

Фомичев C.A. «Вечера на хуторе близ Диканьки» и «Повести покойного Ивана Петровича Белкина». С. 20-21.

Руднева Е.Г. Комизм Гоголя в оценке Белинского. С. 21-22.

Теплинский М.В., Цивкач О.М. Н.В. Гоголь и проблемы развития русской журналистики 30-40-х гг. XIX века. С. 23-24.

Жаркевич Н.М. «Вечера на хуторе близ Диканьки» Н.В. Гоголя в литературно-критическом восприятии 30-40-х гг. ХIX в. С. 24-25.

Мостовская Н.Н. Гоголь и Некрасов. С. 25-26.

Баскаков В.Н. Гоголевская библиография. Традиции, современное состояние, перспективы. С. 26-27.

Кошелев В.А. Гоголь и Константин Аксаков. С. 27-28.

Гин М.М. Достоевский и Некрасов в борьбе за гоголевскую «натуральную школу». С. 29.

Бабичева Ю.В. Гоголь в кино (два киносценария М. Булгакова по Гоголю). С. 30-31.

Левандовский Л.И. Гоголь в русской критике и литературоведении конца XIX - начала XX веков. С. 31-32.

Лявданский Э.К. Творчество Н.В. Гоголя в философско-эстетической концепции Ин. Анненского. С. 33-34.

Голотина Г.А. Нравственно-воспитательный аспект в повестях Н.В. Гоголя «Вечера на хуторе близ Диканьки» (1-й том). С. 34-35.

Коновалов В.Н. Эпистолярное наследие Н.В. Гоголя. С. 35-36.

Мацапура В.И. Гоголь о Пушкине. С. 36-37.

Бельчикова 3.Ф., Розанова Л.А. Н.В. Гоголь, его литературная позиция в оценке члена-корреспондента Академии наук СССР Н.Ф. Бельчикова. С. 38.

Камышалова Л.С. Книги Н.В. Гоголя в библиотеке Лескова. С. 39-40.

Смирнов А.А. Юмор в прозе Н.В. Гоголя и А.С. Пушкина (принципы сопоставления). С. 40-41. Карпенко А.И. «Мертвые души» сквозь «магический кристалл» А.С. Пушкина. С. 41-42.

Мельник Н.Ф., Рымшина Е.В. Особенности авторской позиции в «Старосветских помещиках» Н.В. Гоголя. С. $42-43$.

Горячкина М.С. Традиции Гоголя в сатире Щедрина. С. 44.

Никитина Н.С. Н.В. Гоголь и М.Е. Салтыков-Щедрин. С. 45-46. 
Столярова И.В. Гоголевские традиции в сатире Н.С. Лескова. С. 46-47.

Нагорная Н.М. Гоголевские традиции в повести Н.С. Лескова «Несмертельный голован». C. $47-48$.

Видуэикая И.П. Гоголь и Лесков (к вопросу о творческой преемственности). С. 48-49.

Зарва В.А. Характер сатирического обличения у Н.В. Гоголя и Н.С. Лескова (на материале повести «Детские годы»). С. 50-51.

Мищенко А.К. Традиции Н.В. Гоголя в ранней прозе А.Н. Толстого. С. 51-52.

Березовская B.B. Идейно-эстетические функции детали в повести Н.В. Гоголя «Тарас Бульба» и ранних рассказах Л.Н. Толстого. С. 52-53.

Смирнов В.Б. К проблеме гоголевских традиций в литературном народничестве (Гоголь и Глеб Успенский). С. 53-54.

Маевская Т.П. Традиции романтического пейзажа Гоголя в творчестве Лескова, Короленко, Чехова. С. 55-56.

Силантьева В.И. «Тарас Бульба» Гоголя и «Степь» Чехова (к воплощению темы). С. 56-57.

Удалов В.Л. Драматургия Н.В. Гоголя и А.П. Чехова. С. 57-58.

Крук И.Т. Гоголевские образы в поэтической системе А. Блока. С. 58-59.

Лебеденко Н.П. Гоголевские традиции в циклах А. Блока «Пляска смерти» и «Жизнь моего приятеля». С. 59-60.

Левченко М.А. Н.В. Гоголь в жизни и творчестве В.В. Маяковского. С. 61-62.

Короленок А.И. «Мертвые души» и «Тихий Дон» (Эпические традиции в жанровой структуре романа-эпопеи). С. 62-63.

Зверева Л.И. Традиции Н.В. Гоголя в драматургии А.Н. Толстого. С. 63-64.

Александрова Л.П. Гоголевские традиции в советском романе-эпопее. С. 64-65.

Мартусь В.И. Проблема положительного героя в советской сатире в свете поэтики «Ревизора» и «Мертвых душ» Н.В. Гоголя. С. 65-66.

Назарок М.А. С.Н. Сергеев-Ценский о Гоголе. С. 66-67.

Собин B.A. Отражение народных традиций в творчестве Н.В. Гоголя. С. 68-69.

Карташова И.В. Соотношение романтического и реалистического в прозе Гоголя 30-х гг. С. 69-70.

Маркович B.M. О творческом методе Гоголя в петербургских повестях. С. 71-72.

Булгаков Н.Н. Концепция народности в эстетике Гоголя. С. 72-73.

Пащченко В.А. О природе фантастического в «Вечера на хуторе близ Диканьки». С. 73-74.

Бекедин П.В. В.Г. Белинский и К.С. Аксаков (к спорам о жанре «Мертвых душ» Н.В. Гоголя). С. 74-75. Булат Т.П. Н. Гоголь и музыка. К проблеме интерпретации повестей писателя в музыкально-театральных жанрах. С. 76-77.

Левченко Г.С. Украинская народная песня в творчестве Н.В. Гоголя. С. 77-78.

Дзюба А.А. Н.В. Гоголь и музыкальная культура. С. 78-79.

Слюсарь А.А. О циклизации в прозе Н.В. Гоголя. С. 79-80.

Чальй Д.В. Из наблюдений над поэтикой «Мертвых душ». С. 81.

Воропаев B.A. Поэтика «Мертвых душ» и традиции русского народного творчества. С. 81-82.

Кирилюк 3.В. Традиции создания литературного характера и новаторство гоголевских принципов. С. 83-84.

Марченко Н.Г. Функции сказа в художественной структуре «Мертвых душ». С. 84-85.

Лукавецкая Г.И. Портрет как средство раскрытия характера в «Мертвых душах» Н.В. Гоголя. C. $85-86$.

Лужановский А.B. Роль гоголевской традиции в становлении жанра рассказа. С. 87-88.

Степовик Д.В. Изобразительное искусство как источник образов ранних произведений Н.В. Гоголя. С. 88-89.

Медриш Д.Н. Метафорическая антитеза в поэтической системе Гоголя. С. 89-90.

Губарев И.М. «Арабески» Н.В. Гоголя (об идейно-художественном единстве сборника и своеобразии жанра). С. 91-92.

Дубровина Т.Ю. Фольклорные мотивы в повести Н.В. Гоголя «Портрет». С. 92-93.

Яковлев В.В. Художественное своеобразие повести Гоголя «Записки сумасшедшего». С. 93-94. Поддубная Р.Н. Тип героя и конфликта в «Вие» (к вопросу о барочном характере повести). С. 94-95. Конева T.M. Проблема героического в творчестве Н.В. Гоголя и военной документально-художественной прозе 40-50-х годов. С. 96-97.

Качаева Л.А. Поэзия в прозе (Элементы поэтического языка в пейзажах Н.В. Гоголя). С. 97-98. 
Андрианов Ю.П., Лабунько О.И. Поэтика пейзажа в исторической прозе Н.В. Гоголя. С. 98-99. Балакирева Р.С. Эстетический смысл детали в поэтике Н.В. Гоголя. С. 99-100.

Бурмистрова К.И. Письма Н.В. Гоголя и их роль в развитии мемуарно-автобиографического жанра в русской литературе. С. 100-101.

Звиняцковский В.Я. Образы-символы «Миргорода» Гоголя в интерпретации Чехова и Бунина. C. 102-103.

Дьяченко А.Н. Идейно-эстетические функции и эволюция пейзажа в творчестве Н.В. Гоголя. C. $103-104$.

Свербилова Т.Г. «Ревизор» и проблема гротеска в советской комедии. С. 104-106.

Самойленко Г.В. Н.В. Гоголь в литературоведении народов СССР. С. 106-107.

Сулима Н.М. Традиции украинской древней литературы в творческом наследии Н.В. Гоголя. C. $107-108$.

Михед П.В. Творчество Н.В. Гоголя в системе русско-украинских литературных взаимосвязей. C. $108-109$.

Радченко Е.Е. И.Я. Франко и Н.В. Гоголь. С. 109-110.

Павлюк Н.Н. Н. Гоголь и П. Гулак-Артемовский. С. 110-112.

Заславский И.Я. «Ревизор» в украинских переводах. С. 112-113.

Барабан Л.И. Некоторые аспекты перевода и сценической интерпретации комедии «Ревизор» Н.В. Гоголя на Украине (60-80 гг. ХХ ст.). С. 113-114.

Маркушевский П.Т. «Тарас Бульба» Н.В. Гоголя и украинский театр. С. 114-115.

Микитась В.Л. Н.В. Гоголь и Закарпатье в ХІХ в. С. 116-117.

Охрименко О.П. Н.В. Гоголь в творческой жизни Миколы Садовского. С. 117-118.

Саенко В.П. Гоголевские традиции в творчестве А. Довженко. С. 118-119.

Радецкая М.М. Концепция образа Н.В. Гоголя в советской поэзии. С. 119-120.

Спивак А.И. Гоголь и его герои в художественной интерпретации советских поэтов (Опыт классификации поэтической гоголианы). С. 121-122.

Заморий Т.П. Гоголевские традиции и проблема изображения характера в творчестве М. Стельмаха (на материале романа «Четыре брода»). С. 122-123.

Нахлик E.К. Гоголь и украинская романтическая проза 30-60-х гг. XIX в. С. 123-125.

Ковальчук А.Г. Жанр в системе аксиологических отношений («Набросок драмы из украинской истории» Н. Гоголя и роман П. Загребельного «Я, Богдан»). С. 125-126.

Синиикая В.В., Тюнин А.П. Повесть Н.В. Гоголь «Тарас Бульба» и народная поэзия. С. 126-127. Охрименко П.П. Отзвуки творчества Н.В. Гоголя в белорусской литературе. С. 127-128.

Черных С.Я. Традиции Н.В. Гоголя в творчестве классика марийской литературы Осыпа Шабдаpa. C. $129-130$.

Лебединская Т.Н. Восток в научном и литературном творчестве Н.В. Гоголя. С. 130-131.

Ганич О.Ф. Шевченко и Гоголь. С. 131-132.

Загайко П.К. Традиции Н.В. Гоголя в творчестве Олеся Гончара. С. 132-133.

Полянина Т.В. Проблема славянских связей в мировоззрении и творчестве Н.В. Гоголя. С. 134-135. Михилев А.Д. Н.В. Гоголь и французская сатирическая традиция. С. 135-136.

Волкова Н.Д. Гоголь и Проспер Мериме. С. 136-137.

Гуляев Н.А. «Ревизор» Гоголя в связи с немецким романтизмом. С. 137-138.

Окунь Г.Б. Немецкая революционная драма 20-30-годов и Гоголь. С. 138-139.

Златина Е.Г. Уроки Гоголя в творчестве Джорджа Гиссинга. С. 139-140.

Сверженская E.B. Анна Зегерс о художественном мастерстве Гоголя. С. 141-142.

Сичковская (Михед) T.B. Генезис и характер функционирования формулы «мир - театр» в художественной системе «Мертвых душ» Н.В. Гоголя и «Ярмарке тщеславия» У.М. Теккерея. C. 142-143.

Вовк Я.Г. Традиции Гоголя в испанской литературе: С. 143-144.

Волкова Л.П. Гоголь и Аристофан. С. 144-145.

Покальчук E.B. Традиции Гоголя и современная латиноамериканская литература. С. 145-146.

Василенко В.Н. Элементы гоголевской фантастики в польской литературе начала ХХ века (на материале повести-сказки Болеслава Лесьмяна «Ведьма»). С. 146-147.

Костенко В.Д. Гоголевский «Ревизор» за рубежом. С. 148-149.

Нечепорук Е.И. Н.В. Гоголь в оценке прогрессивной австрийской критике. С. 149-150. 
Арват Н.Н. Авторское своеобразие в построении художественного текста (повесть Н.В. Гоголя «Шинель»). С. 150-152.

Нестеров М.Н. Жанрово-стилистические особенности языка повести Н.В. Гоголя «Тарас Бульба». С. 152-153.

Карагодникова Л.И. Н.В. Гоголь в борьбе за демократизацию русского языка. С. 153-154.

Алефиренко Н.Ф. Образные устойчивые обороты как средство художественной выразительности языка произведений Н.В. Гоголя. С. 154-155.

Бескишкина М.T., Жигилий Н.В. Стилистико-семантические функции фразеологизмов в повестях Н.В. Гоголя «Вечера на хуторе близ Диканьки». С. 156-157.

Варава Н.В., Степаненко Н.И. Стилистическое использование вариантов фразеологических единиц в художественных произведениях Н.В. Гоголя. С. 157-158.

Ярещенко А.П. Лексическая основа эмоционально-смысловых центров в произведениях Н.В. Гоголя. С. $158-159$.

Иванова Л.В. Стилеобразующие функции словообразовательных средств в произведениях Н.В. Гоголя. С. 160-161.

Оголевеи А.В. Языковые средства обобщения и типизации в повести Н.В. Гоголя «Шинель». C. $161-162$.

Гетман И.М., Ломтева Л.И. Анализ ключевых понятий как путь интерпретации образа в поэме Н.В. Гоголя «Мертвые души». С. 162-163.

Гулак А.Т. Стилистика повести Н.В. Гоголя «Портрет». С. 164-165.

Линник Г.Т. Антонимы в поэме Н.В. Гоголя «Мертвые души». С. 165-166.

Алексеенко С.И. Употребление заимствованной лексики в произведениях Н.В. Гоголя. С. 166-167. Семенюченко М.Л. Элементы украинского языка в системе изобразительных средств Н.В. Гоголя. С. 167-168.

Борисенко Н.А. Лексические украинизмы в «Вечерах на хуторе близ Диканьки» Гоголя. С. 169-170. Сологуб Л.А. Устаревшая и устаревающая лексика как изобразительное художественное средство в повести Н.В. Гоголя «Тарас Бульба». С. 170-171.

Лебеденко С.A., Тыминский М.В. Антропонимия повестей миргородского цикла Н.В. Гоголя. C. $172-173$.

Мойсеенко A.K. Качественные существительные в контекстуальном окружении (на материале художественных произведений Н.В. Гоголя). С. 173-174.

Липатов А.T. Глагольные новообразования в языке произведений Н.В. Гоголя как изобразительное средство. С. 175-176.

Казырод Н.И. Словоизменение имен существительных в комедии В.А. Гоголя «Простак». С. 176-177. Бондаревская О.Д. Синонимия фразеологизмов как одно из изобразительных средств в произведениях Н.В. Гоголя. С. 177-179.

Ермак В.Н. Структура словообразовательной парадигмы топонимов в произведениях Н.В. Гоголя. C. $179-180$.

Лихошвай Т.В. О синонимических функциях грамматических форм в петербургских повестях Н.В. Гоголя. С. 180-181.

Вакуленко Н.А., Папина А.Ф. Своеобразие сложного синтаксического целого в поэме-романе «Мертвые души» Н.В. Гоголя. С. 182-183.

Безобразова Л.Л. Коррелятно-союзные предложения как изобразительное средство в произведениях Н.В. Гоголя (на материале сборника «Миргород»). С. 183-184.

Халчанская A.B. Синонимия причинных конструкций как одно из средств речевой выразительности (на материале повести Н.В. Гоголя «Тарас Бульба»). С. 184-185.

Cmacь T.B. Функционирование комбинированных сложных поредложений (на материале произведений Н.В. Гоголя «Тарас Бульба», «Мертвые души»). С. 186-187.

Скаб М.С., Скаб М.В. Ситуативная характеристика обращений в пьесе Н.В. Гоголя «Ревизор». C. $187-188$.

Моргун В.Ф. Психологические типы личности и творчество Гоголя. С. 188-189.

Дановский А.В. Формирование понятия о литературном типе при изучении школьниками поэмы Н.В. Гоголя «Мертвые души». С. 189-191.

Малич М.И. Использование гоголевских образов-персонажей в преподавании общественных наук. С. 191-192.

Шебитченко А.П. Значение творчества Н.В. Гоголя для нравственного воспитания личности. C. 192. 
Базилевич Н.Г., Поколодный Л.Д. Патриотическое воспитание школьников при изучении творчества Н.В. Гоголя. С. 193-194.

Шохирев В.К. Углубление теоретических сведений о композиции произведения при изучении поэмы Н.В. Гоголя «Мертвые души». С. 194-195.

Тарасевич Н.Н. Н.В. Гоголь и проблема личности педагога. С. 195-196.

Ермак А.П. Н.В. Гоголь о преподавании истории. С. 196-197.

Виговская A.A. Осуществление межпредметных и внутрипредметных связей в процессе изучения повести Н.В. Гоголя «Тарас Бульба». С. 198-199.

Крамущенко Л.В. Активизация художественного восприятия учащихся при изучении повести Н.В. Гоголя «Тарас Бульба». С. 199-200.

Шумская А.И., Косенко Н.В. Н.В. Гоголь в литературном краеведении школ Полтавщины. C. 200-201.

Гладченко Н.В., Кривонос И.Ф. Творческое освоение передового педагогического опыта изучения произведений Н.В. Гоголя в школе. С. 201-202.

Тодорова И.С., Мудрак В.И. Психологический анализ гоголевских психологических типов как средство развития перцептивных способностей будущих учителей. С. 202-203.

Томашевский Н. Гоголь и Белли: К 175-летию со дня рождения Н.В. Гоголя // Иностранная литература. М., 1984. № 7. С. 163-165.

Тресков В. Здесь он читал «Ревизора» // Неделя. М., 1984. № 13. С. 18.

Трофимова Н.П. Пушкинские и гоголевские реминисценции в «Деревянной королеве» Л. Леонова // Из истории русской литературы и литературной критики. Кишинев, 1984. C. $135-140$.

Ученые записки Тартуского гос. ун-та. Вып. 664: Семиотика города и городской культуры. Петербург. Труды по знаковым системам. XVIII / Отв. ред. Ю.М. Лотман. Тарту, 1984. $140 \mathrm{c}$.

Из содерж.:

Топоров В.Н. Петербург и петербургский текст русской литературы (введение в тему). С. 4-29. Пумпянский Л.В. Гоголь. С. 125-137.

Федоров B.B. О природе поэтической реальности: монография. М.: Советский писатель, 1984. $184 \mathrm{c}$.

[О Гоголе: С. 90-110, 157-160 («Мертвые души»); С. 120-135 («Тарас Будьба»); С. 154-156, 161-172 («Ревизор»).]

Филин М. О помещике Тремалаханского уезда и о «шалостях потаенных» // Литературная Россия. М., 1984. 30 марта. № 14. С. 18-19.

[Декабристское время в «Мертвых душах»: Попытка нового прочтения.]

Фридлендер Г.М. Гоголь и современность // Русская литература. Л., 1984. № 1. С 3-13.

Хлодовский Р. Рим в мире Гоголя // Иностранная литература. М., 1984. № 12. С. 203-210.

Храпченко М.Б. Николай Гоголь. Литературный путь. Величие писателя. М.: Современник, 1984. 654 с. - (Библиотека «Любителям российской словесности»).

Храпченко М.Б. Подвиг художника: К 175-летию со дня рождения Н.В. Гоголя // Литературная газета. М., 1984. 28 марта. № 13. С. 7.

Чальій Д.В. Из наблюдений над поэтикой «Мертвых душ» // Русский язык и литература в средних учебных заведениях УССР. Киев, 1984. № 4. С. 20-25.

Чеботарева В. О гоголевских традициях в прозе М. Булгакова // Русская литература. Л., 1984. № 1. С. 166-176.

Чудаков А.П. Живые картины // Литературная газета. М., 1984. 28 ноября. № 48(5010). 
[Рубрика: «Внимание: на экране классика». Разговор, в частности, об экранизации М. Швейцером «Мертвых душ».]

Щеблькин И. «Любил он, ненавидя...»// Пензенская правда. Пенза, 1984. 1 апреля.

[К 175-летию со дня рождения Гоголя.]

$<$ Щепкин М.С>. Михаил Семенович Щепкин: Жизнь и творчество: В 2 т. Т. 2: Современнике о М.С. Щепкине. Критика. Из дневников и переписки. Воспоминания / Коммент. Т.М. Ельницкой, Н.Н. Панфиловой, О. М. Фельдман. М.: Искусство, 1984. 479 с.: ил.

Из содерж.:

Щепкин П.М. Первое знакомство Щепкина с Гоголем. С. 267.

Аксаков С.Т. История моего знакомства с Гоголем [Фрагмент.] С. 300-302.

Буслаев Ф.И. Комик Щепкин о Гоголе. С. 310-312.

Тургенев И.С. Литературные и житейские воспоминания [Фрагмент.] С. 349-350.

Оболенский Д.А. О первом издании посмертных сочинений Гоголя [Фрагмент.] С. 350-351.

Коммент. С. 405-428.

Эпитейн М. О значении детали в структуре образа: («Переписчики» у Гоголя и Достоевского) // Вопросы литературы. М., 1984. № 12. С. 134-145.

[Акакий Акакиевич Башмачкин и князь Мышкин.]

Яцеенко M.T. Природа комического в творчестве Котляревского и Гоголя // Русский язык и литература в средних учебных заведениях УССР. Киев, 1984. № 2. С. 14-20.

Gogol a naše doba / Red. J. Klementa. Olomouc: Univ. Halackého, 1984. 136 s. / Материалы международного симпозиума «Гоголь и наше время», состоявшегося в Оломоуце 26-27 апреля 1984 г. На рус. и чеш. яз.

Из содерж.:

Борсукевич Ю. В.Г. Белинский об эволюции художественного метода в творчестве Н.В. Гоголя. Фенина С.В. Традиции Н.В. Гоголя и советская драматургия.

Орловски Я. «Мертвые души» Гоголя и польский сатирический роман 19 века.

Лесюв М. Антропонимия в украинских повестях Гоголя.

Рыцик $X$. Творчество Н.В. Гоголя в учебной программе по русскому языку в польской школе. 458 с.

Peuranen E. Акакий Акакиевич Башмачкин и Святой Акакий // Studia slavica finlandensia. Helsinki, 1984. T. 1. P. 122-133.

\section{5}

\section{ПРОИЗВЕ ДЕНИЯ}

В чем же наконец существо русской поэзии и в чем ее особенность [Фрагмент] // Зарубежная поэзия в переводах В.А. Жуковского. Т. 2 / Сост. А.А. Гугнин. М.: Радуга, 1985. C. $514-517$.

Вечера на хуторе близ Диканьки. Миргород: повести. Владивосток: Дальневосточное книжное изд-во, 1985. $491 \mathrm{c.}$

Вечера на хуторе близ Диканьки. Миргород / Послесл. П. Николаева; ил. А.Г. Антонова. М.: Правда, 1985. 464 с.: ил.

Послесл. С. 449-462.

Вечера на хуторе близ Диканьки: В 2 т. / Вступ. статья и примеч. А. Немзера. М.: Книга, 1985. T. $1.415 \mathrm{c}$.

Загл. вступ. статьи: Сказки Рудого Панька. С. 5-60.

T. $2.527 \mathrm{c}$.

Немзер А.С. Становление Гоголя. С. 5-56.

Примеч. С. 469-526. 
Женитьба / Вступ. статья и послесл. Ю. Манна. М., 1985. 96 с.

Загл. вступ. статьи: Комедийный мир Гоголя. С. 5-11.

Загл. послесл.: История «Женитьбы» в документах. С. 82-94.

Избранные повести. М.: Правда, 1985. 528 с.

Содерж.: Вечера на хуторе близ Диканьки; Тарас Бульба; петербургские повести.

Избранные произведения: В 2 т / Худож. И.Т. Богдеско. Кишинев: Литература артистикэ, 1985.

Т. 1. Вечера на хуторе близ Диканьки; Миргород; Петербургские повести / Вступ. статья П. Николаева; примеч. Н. Степанова, А. Бушмина, Г. Фридлендера. 661 с: ил.

Загл. вступ. статьи: Художественные открытия Гоголя. С. 5-30.

Т. 2. Ревизор; Женитьба; Мертвые души / Примеч. Ю. Манна. 544 с.

Примеч.: С. 522-543.

Приложения:

Повесть о капитане Копейкине (редакция, разрешенная цензурой).

Избранные сочинения / Вступ. статья П. Николаева. М.: Правда, 1985. 672 с.

Загл. вступ. статьи: Художественные открытия Гоголя. С. 3-18

Мертвые души: поэма / Худож. С. Алимов. М.: Художественная литература, 1985. 368 с. (Классики и современники. Русская классическая литература).

Приложение:

Повесть о капитане Копейкине. Редакция, разрешенная цензурой. С. 364-368.

Мертвые души: поэма / [Ил. А. Лаптева]. Таллин: Ээсти раамат [Эстонская книга], 1985. 303 с.: ил.

Миргород: повести, служащие продолжением «Вечеров на хуторе близ Диканьки» / Послесл. и примеч. В.М. Гуминского; худож. Ю.К. Бажанов. М.: Советская Россия, 1985. 256 с.: ил. - (Библиотека юношества).

Загл. послесл.: Мир и герои «Миргорода». С. 219-236.

Примеч. С. 237-251.

Об «Одиссее», переводимой Жуковским (Из письма к Н.М. Я...ву) [Фрагмент] // Зарубежная поэзия в переводах В.А. Жуковского: [В 2 т.]. Т. 2 / Сост. А.А. Гугнина; коммент. К.Н. Атаровой, О.М. Савельевой М.: Радуга, 1985. С. 517-520.

Собр. соч.: В 7 т. / Под общ. ред. С.И. Машинского и М.Б. Храпченко. М.: Художественная литература, 1984-1986.

Т. 4: Драматические произведения / Коммент. Ю.В. Манна. М., 1985. 423 с.

Приложения:

Приложения к комедии «Ревизор»

1. «Ревизор» (Редакция первого издания, 1836 г.). С. 248-324.

2. Две сцены, выключенные как замедлявшие течение пиесы. С. 325-328.

3. Сцена, не внесенная автором в печатные издания «Ревизора». С. 328-329.

4. Отрывок из письма, писанного автором вскоре после первого представления «Ревизора» к одному литератору. С. 329-334.

5. Предуведомление для тех, которые пожелали бы сыграть как следует «Ревизора». С. 334-341.

6. Развязка Ревизора. С. 342-352.

7. Вторая редакция окончания «Развязки Ревизора». С. 353-358.

Владимир 3-ей степени. С. 358-365.

Альфред. С. 365-383.

Наброски драмы из украинской истории. С. 383-386.

Коммент. С. 387-422.

[Сопроводит. статья:] Драматургия Гоголя. С. 387-407.

Коммент. С. 407-422.

Т. 5: Мертвые души: поэма / Коммент. С.И. Машинского. М., 1985. 527 с. 


\section{Приложения:}

Повесть о капитане Копейкине (Редакция, разрешенная цензурой). С. 474-479.

$<$ Заметки> к 1-й части. С. 479-480.

Предисловие ко второму изданию первого тома «Мертвых душ». С. 481-484.

Коммент. С. 485-525.

[Сопроводит. статья:] «Мертвые души»: С. 486-511.

Коммент. С. 512-525.

Шинель: повесть / Послесл. Ю.В. Манна; рис. Ю. Игнатьева. М.: Детская литература, 1985. 47 с. - (Школьная библиотека).

Загл. послесл.: «Одно из величайших созданий Гоголя». С. 39-46.

Шинель: [повесть] / Ил. С. Бродского М.: Художественная литература, 1985. 79 с.: ил.

Шинель: [повесть.] Свердловск: Средне-Уральское книжное изд-во, 1985. 127 с.

\section{ЛИТ ЕРАТ У РА}

Алексеев М.П. Русская культура и романский мир: избранные труды / АН СССР, Отделение лит. и яз.; отв. ред. [и авт. послесл.] Ю.Б. Виппер, П.Р. Заборов. Л.: Наука: Ленинградское отделение, 1985. 542 с.: ил.

[Указ. имен.]

Антонова Т.И. Лирическая строфа Гоголя // Вопросы стилистики. Саратов, 1985. Вып. 20. С. 112-122.

Aсоян A.A. Заметки о дантовских мотивах у Белинского и Гоголя // Дантовские чтения 1985. М.: Наука, 1985. [Вып. 7.] С. 104-119.

Бахрах А. Гоголь в новых отражениях // Новое русское слово. Нью-Йорк, 1985. 4 августа. С. 5. [Обзор 17-го тома ежегодника «Записки русской академической группы в США» (1984), посвященного творчеству Гоголя.]

Беглов B.A. О некоторых типологических связях эпического характера в «Тарасе Бульбе» Н.В. Гоголя и «Кому на Руси жить хорошо» Н.А. Некрасова // Изучение преемственных связей в русской и советской литературе: межвузовский сб. Горький, 1985. С. 36-40.

Беловинский Л.В. Культура слова (Актуальный вопрос) // Новый мир. М., 1985. № 8. C. 244-247.

Белоусов А.Ф. Процесс познания как художественная проблема («петербургские» повести в «Арабесках») // Литературный процесс и развитие русской культуры XVIIIXX вв. Тезисы научной конференции. Таллин, 1985. С. 94-98.

Бердников Г.П. Над страницами русской классики. М.: Современник, 1985. 415 с.

Из содерж.:

Гоголь и Чехов. С. 71-103.

Исторические судьбы творческого наследия Гоголя. С. 33-70.

Бибихин В.В., Гальиева Р.А., Роднянская И.Б. Гоголь и русская действительность (Идейные споры на страницах западных исследований). М., 1985.

Библиография литературы о Н.В. Гоголе (1962-1966) / Сост. В.П. Казарин; Министерство высшего и среднего специального образования УССР; Симферопольский гос. ун-т им. М.В. Фрунзе. Симферополь: СГУ, 1985. 19 с.

Библиография художественной литературы и литературоведения: [Учебник для студентов институтов культуры, педагогических вузов и университетов] / Под ред. С.А. Трубникова. М.: Книга, 1985. 335 с. 
[Указ. имен.]

Богомолова Е.И., Жаров Т.К., Кедрова М.М. Пособие по литературе для слушателей подготовительных отделений высших учебных заведений: Учебное пособие. 2-е изд., испр. и доп. М.: Высшая школа, 1985. 431 с.

Гл. 5: Николай Васильевич Гоголь (1809-1852). С. 148-161.

«Ревизор». С. 149-154.

«Мертвые души». С. 154-159.

Бочаров С.Г. О художественных мирах. М.: Советская Россия, 1985. 296 с.

Из содерж.:

Загадка «Носа» и тайна лица. С. 124-160.

Переход от Гоголя к Достоевскому. С. 161-209.

[Рец.: Бабаев Э. Сообщающиеся миры // Новый мир. М., 1988. № 2. С. 250-253.]

«Ваш брат Николай Гоголь» Из писем сестрам (1836-1851 гг.) / Вступ. заметка Н. Булгакова // Парус. М., 1985. Вып. 5. С. 162-181.

Виролайнен М.Н. Гоголь и Лермонтов (проблема стилистического соотношения) // Лермонтовский сборник / АН СССР, Институт русской литературы (Пушкинский Дом); редкол.: И.С. Чистова (отв. ред.) и др. Л.: Наука, 1985. С. 104-130.

Bоропаев B., Воропаева Е. И.М. Снегирев и литературная Москва // Москва литературная: сб. статей московских критиков / Сост. В. Гусев. М.: Московский рабочий, 1985. С. 184-196. [Гоголь и И.М. Снегирев.]

$<$ Гоголь Н.В.> Н.В. Гоголь: История и современность: К 175-летию со дня рождения / Сост. В.В. Кожинов, Е.И. Осетров, П.Г. Паламарчук. М.: Советская Россия, 1985. 493 с. Содерж.:

Кожинов В.В. Вместо предисловия. С. 3-14.

I:

Щербина В.Р. Н.В. Гоголь. С. 16-74.

Михалков С.В. Слово о Гоголе. С. 75-78.

Бурсов Б.И. Родник русского реализма. С. 79-84.

Палиевский П.В. Место Гоголя в русской литературе. С. 85-93.

Михайлов А.В. Гоголь в своей литературной эпохе. С. 94-131.

Федоров В.В. Поэтический мир Гоголя. С. 132-162.

Фридлендер Г.М. Гоголь и современность. С. 163-178.

II:

Бочаров С.Г. Загадка «Носа» и тайна лица. С. 180-212.

Манн Ю.В. Заметки о поэтике Гоголя. С. 213-239.

[Главы из книги «Поэтика Гоголя».]

Гуминский В.М. «Тарас Бульба» в «Миргороде» и «Арабесках». С. 240-258.

Чудаков А.П. Вещь в мире Гоголя. С. 259-280.

Скатов Н.Н. Иван Александрович Хлестаков - и другие. С. 281-291.

Золотусский И.П. Еще о «Ревизоре». С. 292-307.

Казинцев А.И., Казинцева Н.А. Автор двух поэм. С. 308-324.

III:

Осетров Е.И. Гоголь и «Слово о полку Игореве». С. 326-332.

Гусев В.И. Порыв к высокому. Заметки на тему «Гоголь и романтизм». С. 333-338.

Сахаров В.И. Суровый наследник (Гоголь и Лев Толстой). С. 339-347.

Горелов П.Г. О повести «Старосветские помещики». С. 348-359.

Чудакова М.О. Гоголь и Булгаков. С. 360-388.

IV:

Бибихин В.В., Гальщева Р.А., Роднянская И.Б. Литературная мысль Запада перед «загадкой» Гоголя». С. 390-433.

Воропаев В. Три этюда о Гоголе (Из архивных разысканий). С. 434-467.

Рязанова Л.А. Пришвин о Гоголе: С. 469-483. 
Паламарчук П.Г. Список уцелевших от сожжения рукописей Гоголя. С 484-491.

[Рец.: Пенская Е.Н. Гоголь - наш современник // Литература в школе. М., 1986. № 2. С. 67-69; Галиуллин Т. Книга о Гоголе // Наш современник. М., 1987. № 3. С. 185-186.]

Голубков С.А. О некоторых традициях Н. Гоголя и Л. Толстого в прозе А.Н. Толстого // Классические традиции в русской советской литературе. Куйбышев, 1985. С. 91-103.

Гончаров С.A. Соотношение литературно-критических и публицистических статей Н.В. Гоголя с текстом «Мертвых душ» (К постановке проблемы) // Проблемы литературно-критического анализа. Тюмень: Изд-во Тюменского ун-та, 1985. С. 100-107.

Григорьев А.А. Театральная критика / Вступ. статья А.Я. Альтшуллера и Б.Ф. Егорова; сост., примеч. Т.Б. Забозлаевой, Л.С. Даниловой, И.В. Кудряшевой. Л.: Искусство, 1985. 407 с.

Загл. вступ. статьи: Аполлон Гритгорьев - театральный критик. С. 3-27.

Примеч. С. 345-375.

[Указ. имен.]

Гронская A.B. Украинизмы в русской прозе Н.В. Гоголя как тип речевой экспрессии (На материале «Повести о том как Иван Иванович поссорился с Иваном Никифоровичем») // Вопросы восточнославянского языкознания. Днепропетровск, 1985. С. 105-107.

Гуминский В.М. Пенаты: Уроки русской классической литературы. М.: Молодая гвардия, 1985. 111 с.: ил. - (Библиотека журнала ЦК ВЛКСМ «Молодая гвардия». № 12(171). Гоголь и четыре урока «Миргорода».

Степной царь.

Денисов В.Д. Мертвые души царской России // Русский язык в башкирской школе. 1985. № 1. С. 51-52.

Евреинов Ю.Н. Ценность, которая принадлежит всем // Строительство и архитектура. Киев, 1985. № 1. С. 3-9.

Ерофеев B. На грани разрыва: («Мелкий бес» Ф. Сологуба на фоне русской реалистической традиции) // Вопросы литературы. М., 1985. № 2. С. 140-158.

Диалектова A.В. М.М. Бахтин о жанре воспитательного романа (Н.В. Гоголь, И.А. Гончаров) // Проблемы научного наследия М.М. Бахтина: межвузовский сб. научных трудов. Саранск: Изд-во Мордовского гос. ун-та, 1985. С. 41-51.

Жуковский В.А. Эстетика и критика / Вступ. статья Ф.З. Кануновой и А.С. Янушкевича; сост. и примеч. Ф.З. Кануновой, О.Б. Лебедевой и А.С. Янушкевича. М.: Искусство, 1985. 431 с. - (История эстетики в памятниках и документах).

Загл. вступ. статьи: Своеобразие романтической эстетики и критики В.А. Жуковского. С. 7-48.

Из содерж.:

Статьи 1840-х годов

О поэте и современном его значении. Письмо к Н.В. Гоголю. С. 328-338.

Примеч. С. 416-417.

[Впервые: Москвитянин. 1848. № 4. С. 11-26.]

[Указ. имен.]

Заповедник-музей Н.В. Гоголя: Путеводитель / [Авт. текста Н.В. Хоменко, А.П. Тюнин]. Харьков: Прапор, 1985. 54 с.: ил.

Захарова В.А. Творчество Н.В. Гоголя в освещении критики 90-900-х гг. // Ученые записки Ярославского пед. ин-та. Ярославль, 1985. Вып. 25. С. 583-611.

Звиняциковский В.Я. «Сын Альбиона», или История двух экспедиций. Чехов и «англичанин Морган» на родине Гоголя // Вопросы литературы. М., 1985. № 4. С. 274-277. 
Зиман Л.. «Поэт, открытый Гоголем». Об одном эпизоде русско-итальянских литературных связей // Альманах библиофила. Вып. 18. М.: Книга, 1985. С. 197-205.

[Римский поэт Джузеппе Джоанино Белли.]

Золотое слово Н.В. Гоголя. 1809-1852: «Ваш брат Николай Гоголь». Из писем сестрам // Парус: сб. литературно-художественных и публицистических произведений. Вып. 5 / Сост. Л.А. Белая. М.: Молодая гвардия, 1985. С. 162-181.

Иванов А. Экология исторических памятников и могил. Н.В. Гоголь: Возвращение на Родину. Смерть. Посмертная судьба // Новый журнал. Нью-Йорк, 1985. № 161. С. 271-285. [Последние годы жизни Гоголя, его завещание и похороны. Могила писателя в Москве.]

Исупов К.Г. Эстетика истории в «Риме» Гоголя // Литературный процесс и развитие русской культуры XVIII-XX вв. Тезисы научной конференции. Таллин, 1985. С. 98-100.

Казарин В.П. Комедия Н.В. Гоголя «Ревизор» в контексте романтической драмы // Жанры в историко-литературном процессе. Вологда, 1985. С. 45-59.

Карпенко А.И. У истоков гоголевской поэмы «Мертвые души» // Вопросы русской литературы. Львов, 1985. Вып. 1(45). С. 36-44.

[Гоголь и А.С. Пушкин].

Ковалева Ю.Н. К спорам о втором томе «Мертвых душ» Н.В. Гоголя (Об идейно-художественных исканиях писателя в последний период творчества) // Русская классическая литература и современность. Воронеж, 1985. С. 49-60.

Кокарев B.A. «Письмо из провинции» Н.П. Огарева в свете гоголевских традиций // Проблемы творчества Н.П. Огарева: межвузовский сб. научных трудов / Министерство высшего и среднего специального образования РСФСР; Мордовский гос. ун-т им. Н.П. Огарева. Саранск, 1985. С. 32-48.

Колосова Н. Смирнова и Гоголь // Кавкасиони: Литературный сб. Тбилиси, 1985. Вып. 3. C. $189-240$.

[Фрагмент книги «А.О. Смирнова и русские писатели XIX века».]

Косоруков А. По былям сего времени // Москва. М., 1985. № 12. С. 145-160.

[К 800-летию «Слова о полку Игореве».]

[Родство художественных натур Гоголя и автора «Слова о полку Игореве».]

Кривонос В.Ш. Притча о Кифе Мокиевиче и ее роль в «Мертвых душах» // Известия АН СССР. Сер. лит. и яз. М., 1985. Т. 44. № 1. С. 48-55.

Кривонос В.Ш. «Мертвые души» Гоголя и становление новой русской прозы: Проблемы повествования: монография / Науч. ред. В.П. Скобелев. Воронеж: Изд-во Воронежского ун-та, 1985. 159 с.

Кубарев Е.М. Стилистические функции повторов в речевой «самохарактеристике» Хлестакова (На основании текстологического сопоставления авторских вариантов комедии Н.В. Гоголя «Ревизор») // Функциональный и семантический аспекты изучения лексики. Куйбышев, 1985. С. 141-157.

Лиходеев Л. 3:2 в пользу Гоголя // Неделя. М., 1985. № 1(1293). С. 18-19.

[Заметки о телефильме М. Швейцера «Мертвые души».]

Лозбэ М. Повтор - художественный прием гоголевской стилистики и поэтики («Мертвые души») // Analele şti ale Univ. Al. I. Cuza din laşi. Secţ. 3-e, Linguistica, 1985. T. 31. C. 55-61. 
Майков В.Н. Литературная критика. Статьи. Рецензии / Сост., подгот. текста, вступ. статья, примеч. Ю.С. Сорокина. Л.: Художественная литература, 1985. 408 с.: ил. - (Русская литературная критика).

Загл. вступ. статьи: В.Н. Майков и его литературно-критическая деятельность. С. 3-32.

Из содерж.:

Стихотворения Кольцова. С портретом автора. его факсимиле и статьею о его жизни и сочинениях. СПб, 1846. С. 67-176.

Примеч. С. 355-366.

[Впервые: Отечественные Записки. 1846. Т. 49. Отд. V. № 11. С.1-38; № 12. С. 39-70. Без подписи.] Нечто о русской литературе в 1846 году. С. 177-200. Без подписи.

Примеч. С. 366-369.

[Впервые: Отечественные Записки. 1847. Т. 50. № 1. Отд. V. С. 1-17. Без подписи.]

Похождения Чичикова, или Мертвые души. Поэма Н. Гоголя. Изд. 2-е. М., 1846. В университетской тип. С. 296.

Примеч. С. 380.

[Впервые: Отечественные Записки. 1846. Т. 49. № 12. Отд. VI. С. 57. Без подписи.]

Выбранные места из переписки с друзьями Николая Гоголя. СПб.: В тип. Департамента внешней торговли. С. 297-299.

[Печатается по рукописи.]

Примеч. С. 381-382.

[Впервые: Отечественные Записки. 1847. Т. 50. № 2. Отд. VI. С. 69-71. Без подписи.]

Сто рисунков из сочинения Н.В. Гоголя «Мертвые души». Издание Е.Е. Бернардского и А. Г. Рисовал А. Агин, гравировал на дереве Е. Бернардский. СПб.: В тип. Э. Праца, 1846. Вып. I-XII. C. $300-324$.

Примеч. С. 382-384.

[Впервые: Отечественные Записки. 1847. Т. L. № 2. Отд. VI. С. 71-88.]

[Указ. имен.]

Макогоненко Г.П. Гоголь и Пушкин: Монография. Л.: Советский писатель, 1985. 352 с.

[Рец.: Сурков Е. Гоголь и Пушкин: проблемы и решения // Вопросы литературы. М., 1986. № 5. С. 234-241; Карпов А. Проблемы литературной преемственности // Звезда. Л., 1986. № 7. С. 202-204; Мазья М. Родословная русского реализма // Нева. Л., 1986. № 6. С. 165-166; Моторин А.В. // Научные доклады высшей школы. Филологические науки. М., 1987. № 1. С. 83-85.]

Манн Ю.В. Гоголевские мемуары (Н.В. Гоголь в Риме летом 1841 года) Анненкова как эстетический документ // Проблемы изучения культурного наследия: [сб. статей] / АН СССР, Научный совет по истории мировой культуры; отв. ред. Г.В. Степанов. М.: Наука, 1985. С. 251-256.

Манн Ю.В. Еще раз о «тайне лица» Гоголя // Литературная учеба. М., 1985. № 5. С. 200-203.

Манн Ю.В. О мировом значении Гоголя // Славянские культуры и мировой культурный процесс: Материалы международной научной конференции ЮНЕСКО / Редкол.: С.В. Марцелев (отв. ред.) и др. Минск: Наука и техника, 1985. С. 218-222.

Манн Ю. «Открыть человека в человеке» // Достоевский Ф.М. Бедные люди. М., 1985. C. 5-23.

Манн Ю.В. Смелость изобретения: Черты художественного мира Гоголя / Худож. В. Сергеев. 3-е изд. М.: Детская литература, 1985. 144 с.: ил.

Михед П.В. Гоголь и Сильвио Пеллико // Литературный процесс и развитие русской культуры XVIII-XX вв. Тезисы научной конференции. Таллин, 1985. С. 23-25.

Молдавский Д. «Мастерство Гоголя». Заметки о книге А. Белого // Андрей Белый. Проблемы творчества. М.: Советский писатель, 1985. С. 269-281. 
Носов В.Д. [Паламарчук П.Г.] «Ключ» к Гоголю. Опыт художественного чтения / Вступ. статья Б. Филиппова. London: Overseas Publications Interchange Ltd, 1985. 1985. 133 с. Загл. вступ. статьи: Вокруг Гоголя. Вереница цитат и размышлений. С. 5-24.

[Рец.: Радашкевич А. Коротко о книгах // Русская мысль. Париж, 1986. 7 марта. № 3611. С. 10; Кублановский Ю. Тайна Гоголя // Русская мысль. Париж, 1986. 30 мая. № 3623. С. 10.]

[Перепечатано: Паламарчук П.Г. Козацкие могилы: Повести, сказания, художественные исследования. М., Современник, 1990. С. 336-422; Паламарчук П. Свиток. Сборник прозы. [М.:] Паломник, 2000. С. 153-244.]

Овчарова П.И. Жанровое своеобразие повести Гоголя «Шинель» // Поэтика реализма. Куйбышев, 1985. С. 47-62.

Павлов Н.Ф. Сочинения / Сост., послесл. и примеч. Л.М. Крупчанова. М.: Советская Россия, 1985. 304 с.

Загл. послесл.: Н.Ф. Павлов. С. 279-290.

Из содерж.:

Письма Н.Ф. Павлова к Н.В. Гоголю по поводу его книги «Выбранные места из переписки с друзьями».

Первое письмо. С. 254-265.

Второе письмо. С. 265-271.

Четвертое письмо. С. 271-278.

[Впервые: Московские Ведомости. 1847. № 28, 38, 46; перепечатано: Современник. 1847. Май, Август.]

Примеч. С. 301-302.

Памятники культуры. Новые открытия: Письменность. Искусство. Археология. Ежегодник 1983 / Академия наук СССР, Научный совет по истории мировой культуры; редкол.: Д.С. Лихачев (пред.) и др. Л.: Наука. Ленинградское отделение, 1985. 538 с.

Из содерж.:

Белеикий А.П. Исследование и восстановление усадьбы Н.В. Гоголя в Полтавщине.

Паперный 3.С. Гоголь в восприятии Чехова // Известия АН СССР. Сер. лит. и яз. М., 1985. T. 44. № 1. C. 68-71.

Пенская E. Необъятный мир Гоголя: По залам выставки «Николай Васильевич Гоголь» в Государственном литературном музее // Альманах библиофила. М., 1985. Вып. 18. C. $189-196$.

Пляшко Л.А. Город, писатель, время: Нежинский период жизни Н.В. Гоголя / Отв. ред. Ф.П. Шевченко. Киев: Наукова думка, 1985. 112 с.: ил. - (Научно-популярная литература). [Рец.: Михед П. // Радянское літературознавство. Киів, 1987. № 9. С. 74-75.]

Пустығина Н.Г. Принцип приближения/удаления в творчестве Н.В. Гоголя // Литературный процесс и развитие русской культуры XVIII-XX вв. Тезисы научной конференции. Таллин, 1985. С. 91-94.

Раков Ю. Где мог жить Башмачкин? // Литературная Россия. М., 1985. 29 марта.

Саркисова Н.Н. В. Вартанянц о творчестве Н. Гоголя и Г. Успенского // Вестник Ереванского ун-та. Общественные науки. Ереван, 1985. № 2. С. 126-130.

Семенов Р. Афанасий Иванович и Аграфена Максимовна, или Образ селянина у Гоголя и Платонова // Литературная учеба. М., 1985. № 6. С. 183-193.

Скатов Н.Н. Иван Александрович Хлестаков и другие // Скатов Н.Н. Литературные очерки. М., 1985. С. 20-30.

Слюсарь A.A. Сатира в русской и украинской прозе 30-х гг. ХІХ в. («Повесть о том, как поссорился Иван Иванович с Иваном Никифоровичем» Н. Гоголя и «Пан Халявский» 
Г. Квитки-Основьяненко) // Вопросы литературы народов СССР. Киев; Одесса, 1985. Вып. 11. С. 92-103.

Степанов В.Г. Английские переводы гротескных аномалий в «Мертвых душах» Н.В. Гоголя (перевод издательства «Визетелли» 1887 года, переводы Д. Хогарта, К. Гарнет, Д. Магаршака) // Системно-типологическое описание языков и литературы. М., 1985. С. 254-262.

Сто рисунков из сочинения Н.В. Гоголя «Мертвые души» / Рисовал А. Агин, гравировал Е. Бернардский. М.: Книга, 1985. разд. паг. Факсимильное изд.: 72 гравюры. Вып. 1846 г. и 31 гравюры. Вып. 1892 г. с отдельным приложением: Г.Ю. Стернин. Иллюстрации А.А. Агина и Е.Е. Бернардского к «Мертвым душам» Н.В. Гоголя: 1892. 32 с.

\section{[Приложение:]}

Вступительный текст к изданию 1892 г. От издателя. С. 30.

Лесков Н. Об иллюстрациях «Мертвых душ». С. 30-32.

Строганов М.В. Творчество М.Ю. Лермонтова и Н.В. Гоголя в восприятии Л.Н. Толстого: Учебное пособие / Калининский гос. ун-т. Калинин, 1985. 55 с.

Сугай Л.А. Брюсов - исследователь и интерпретатор Гоголя // Брюсовские чтения 1983 года. Ереван: Советакан грох, 1985. № 4. С. 141-153.

«Судила здраво и светло...»: Из «Автобиографических записок» А.О. Смирновой-Россет / Вступ. и подгот. текста С. Житомирской // Литературная газета. М., 1985. 13 февраля. № 7. С. 6.

[О Гоголе, А.С. Пушкине, Ф.И. Тютчеве.]

Султанова Ш.И. Творчество Н.В. Гоголя в освещении периодической печати Туркестана конца XIX - начала XX века // Общественные науки в Узбекистане. Ташкент, 1985. № 7. C. 48-51.

Тарасов Б.Н. В мире человека. М.: Современник, 1985. 319 с.

Н.В. Гоголь и Чаадаев (тема единства в сознании мыслителя и писателя).

Тер-Оганесян И. Традиции гоголевской реалистической фантастики в романе Ю. Олеши «Зависть» // Труды / Тбилисский ун-т. Совет молодых ученых. Тбилиси, 1985. Вып. 11. С. 308-315.

Толстой Л.Н. О Гоголе // Толстой Л.Н. Что такое искусство? М.: Современник, 1985. C. $340-341$.

Труайя А. Гоголь в Париже / Публ. Н.Т. Унанянц // Литературная Армения. Ереван, 1985. № 9. С. 87-90.

Урнов Д.М. Гоголь и Диккенс // Известия АН СССР. Сер. лит. и яз. М., 1985. Т. 44. № 1. C. $38-47$.

Фейзуллаева А. Н.В. Гоголь на азербайджанском языке // Известия АН АзССР. Сер. лит., яз. и искусства. Баку, 1985. № 3. С. 25-29.

Фридкин В.М. Отчет о командировке // Наука и жизнь. М., 1985. № 2.

Храпченко М.Б. Метаморфозы критического субъективизма // Новый мир. М., 1985. № 11. C. 225-242.

[Критический анализ работ советских литературоведов последних лет, посвященных творчеству Гоголя.]

Чальй Д.В. Пушкин и Гоголь // Теория и история литературы. К 100-летию со дня рождения академика А.И. Белецкого. Киев: Наукова думка, 1985. С. 96-101. 
Черевацкая Б.В. Стилистические особенности антитез в лирических отступлениях «Мертвых душ» Гоголя / Казанский гос. ун-т им. В.И. Ульянова-Ленина. Казань, 1985. 37 с.

Чичерин А.В. Очерки по истории русского литературного стиля. Повествовательная проза и лирика. 2-е изд., дополн. М.: Художественная литература, 1985. 447 с.

Гл. 3: Гоголь. С. 117-140.

[Указ. имен.]

Шаров А. Волшебники приходят к людям: Книга о сказке и о сказочниках. М.: Детская литература, 1985.320 с.: ил.

Встреча с Гоголем. С. 43-47.

[С.Т. Аксаков и Гоголь.]

Янушкевич А.С. Этапы и проблемы творческой эволюции В.А. Жуковского. Томск: Изд-во Томского ун-та, 1985. 285 с.

В.А. Жуковский и Н.В. Гоголь. С. 265-273.

Автор-составитель:

Владимир Алексеевич Воропаев,

доктор филол. наук

профессор

филологический факультет

МГУ имени М.В. Ломоносова
Vladimir A. Voropaev,

Doctor of Philology

Professor

Philological Faculty

Lomonosov Moscow State University

voropaevvl@bk.ru 